\title{
The Immigrant and Native-Born Wage Distributions: Evidence from United States Censuses
}

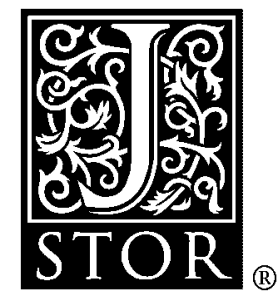

\author{
Kristin F. Butcher; John Dinardo \\ Industrial and Labor Relations Review, Vol. 56, No. 1. (Oct., 2002), pp. 97-121.
}

Stable URL:

http://links.jstor.org/sici?sici=0019-7939\%28200210\%2956\%3A1\%3C97\%3ATIANWD\%3E2.0.CO\%3B2-H

Industrial and Labor Relations Review is currently published by Cornell University, School of Industrial \& Labor Relations.

Your use of the JSTOR archive indicates your acceptance of JSTOR's Terms and Conditions of Use, available at http://www.jstor.org/about/terms.html. JSTOR's Terms and Conditions of Use provides, in part, that unless you have obtained prior permission, you may not download an entire issue of a journal or multiple copies of articles, and you may use content in the JSTOR archive only for your personal, non-commercial use.

Please contact the publisher regarding any further use of this work. Publisher contact information may be obtained at http://www.jstor.org/journals/cschool.html.

Each copy of any part of a JSTOR transmission must contain the same copyright notice that appears on the screen or printed page of such transmission.

JSTOR is an independent not-for-profit organization dedicated to and preserving a digital archive of scholarly journals. For more information regarding JSTOR, please contact support@jstor.org. 


\title{
THE IMMIGRANT AND NATIVE- BORN WAGE DISTRIBUTIONS: EVIDENCE FROM UNITED STATES CENSUSES
}

\author{
KRISTIN F. BUTCHER and JOHN DINARDO*
}

\begin{abstract}
Recent studies document a large widening of the immigrant/native-born mean wage gap since about 1970 , a trend that some observers ascribe to post1965 changes in U.S. immigration policy. These studies are limited, however, by their exclusive focus on men, which ignores important gender differences in the wage gap, and by the inadequacy of the mean wage for characterizing the gap when, as in recent decades, the wage distribution dramatically changes. This study of recent immigrants examines changes across the entire wage distribution, for both genders. The authors find evidence, based partly on gender differences, that minimum wages strongly influenced the gap. A counterfactual analysis also indicates that if recent immigrants in 1970 had faced the 1990 wage structure, their wage distribution would have closely resembled that of recent immigrants in 1990. These and other results suggest that the increasing wage gap is linked to changes in the wage structure.
\end{abstract}

G iven the substantial interest in comparisons of wages between immigrants and the native-born, and the demand for simple models that describe how these changes have evolved over time, it is natural that previous work has focused on explaining differences in the mean wage between these two groups, especially as a function of changing immigration policies (see,

*Kristin F. Butcher is a Senior Economist in the research department of the Federal Reserve Bank of Chicago. John DiNardo is a Research Associate at the National Bureau of Economic Research and Professor of Economics and Public Policy in the Gerald R. Ford School of Public Policy, University of MichiganAnn Arbor. For helpful comments, the authors thank David Card, Anne Morrison Piehl, Jean Wohlever, and seminar participants at Boston College, Princeton University, the University of Illinois, USC, and the NBER summer institute. for example, Borjas 1990, 1995; Jasso, Rosenzweig, and Smith 2000). When the distribution of wages is changing, however, it is plain that an analysis of the mean wage of various subgroups may not completely characterize the differences between these subgroups.

That simple observation motivates the current paper, in which we provide a descriptive analysis of the changes in the distribution of wages of immigrants and the native-born using data from 1960-90. The core of our analysis is a series of estimated wage distributions for immigrants and the native-born. This allows us to expand the discussion from a single wage gap (such as

The data and programs used to generate the results presented in the paper are available from the second author upon request. 
the mean log wage gap) to comparisons at various points in the distribution. In doing so, we highlight the importance of secular changes in the wage structure to these comparisons. For example, the very different evolution of male and female wage structures over the period 1960 to 1990 leads to a divergence in the time path of immigrant/native-born wage gaps for men and women. ${ }^{1}$

\section{Background and Summary Statistics}

In this study, we re-evaluate the evidence on changes in immigrant earnings and immigrant characteristics over time. Our analysis is similar in spirit to that of LaLonde and Topel (1992), who noted that most immigrant/native-born comparisons assume "constant period effects"; for example, if immigrants have always been concentrated in the bottom tail of the wage distribution, and the wage distribution widens, then immigrant/native-born comparisons will show a relative decline in immigrants' earnings-even if there has been no underlying change in the characteristics of immigrants vis-a-vis the native-born. LaLonde and Topel recommended comparing immigrants to native-born workers-for example, native-born Hispanics-who would have experienced similar wage changes due to the overall change in the distribution of earnings. Using this comparison group, they showed substantial assimilation of immigrants. Yuengert (1994) made a related point, demonstrating that the choice of where in the distribution to make earning comparisons has implications for immigrant/native-born wage comparisons that differ from those that arise from computing simple means.

We adapt techniques appropriate for analysis of the entire distribution of wages

\footnotetext{
${ }^{1}$ For more on the demographic characteristics and labor market outcomes of male and female immigrants, see Duleep and Sanders (1993), Beach and Worswick (1993), Baker and Benjamin (1997), and Schoeni (1998).
}

to disentangle two influences on comparisons of native-born and immigrant wages between 1960 and 1990: the enormous changes in the structure of wages, and the striking changes in immigrant characteristics.

\section{Data}

The data used in this paper are from the $1960,1970,1980$, and 1990 Public Use Microdata Samples of the U.S. Censuses. ${ }^{2}$ The 1960 data are a $1 \%$ sample of the population. The 1970 data are also a $1 \%$ sample (from the $5 \%$ State sample). The 1980 and 1990 data are from the $5 \%$ samples; however, only a random subset of each of these is used in the analyses presented here.

In all cases, the data refer to men and women between the ages of 16 and 65 , inclusive. Individuals born abroad to American parents and those born in U.S. outlying areas (for example, Puerto Rico) have been dropped from the analysis. Immigrants are defined as those who were born outside the United States. We drop the self-employed in the main analysis.

Across the four Censuses used here, there were several changes in the way certain information was coded. In all cases, we attempted to define our variables in a consistent way. These changes affect some of the analyses we are able to perform. For example, although the 1970-90 Censuses give fairly detailed information on the time period during which an immigrant entered the United States, the 1960 Census does not. The 1960 Census does, however, allow us to identify those who entered within the last five years. For consistency, we define "recent" immigrants as those who immigrated within the last five years in all our data.

Much of our analysis focuses on log hourly wages. We calculate these from informa-

\footnotetext{
2The data refer to the year prior to the census date. For example, the wage data are for 1959, 1969, 1979, and 1989. However, we will refer to everything by the census date.
} 
tion reported on total annual earnings from wages and salary, number of weeks worked, and usual hours worked per week. ${ }^{3}$ We use the implicit price deflator for GNP total personal consumption expenditures to convert all wages into 1990 dollars. ${ }^{4}$ Many analyses using census data use weekly wages rather than hourly wages, since these calculated hourly wages may be prone to measurement error. However, weekly wages confound wage rates and labor supply. Furthermore, our comparisons of mean hourly wages of immigrants and the nativeborn look very similar to results from studies that instead use mean weekly wages.

\section{Descriptive Statistics}

Appendix Tables A1 and A2 show summary statistics for the native-born, all immigrants, and recent immigrants for men and women in all four decennial Censuses. These tables confirm the changes in immigrant characteristics that other researchers have documented (Borjas 1990). For example, consider the percentages of immigrants by educational attainment (less than high school degree; high school graduation; some college; college degree or better). ${ }^{5}$ Although the fraction of immigrant men with less than a high school degree fell from $69 \%$ to $41 \%$ between 1960 and 1990 , an even greater shrinkage of this categoryfrom $56 \%$ to $22 \%$-occurred among native-born men over the same period. (The decline in this category for immigrant

\footnotetext{
${ }^{3}$ In 1960 and 1970 the data are only available in bracketed form. We assign the midpoint of each bracket and calculate the hourly wage rates.

${ }^{4}$ In all years, we trim out those with log wages (in 1990 dollars) less than zero ( $\$ 1$ per hour) or greater than six ( $\$ 403.43$ per hour).

${ }^{5}$ These variables are defined based on the highest grade attended and highest grade completed as reported in the 1960-1980 Censuses. There was a change in the education codes in the 1990 Census. In all cases, highest grade completed $<12=$ high school dropout; highest grade completed $=12=$ high school degree; $13 \leq$ highest grade completed $<16=$ some college; highest grade completed $\geq 16$ = college graduate.
}

women was from $68 \%$ to $39 \%$.) Thus, by 1990 immigrants were substantially more likely to be high school dropouts than were the native-born. This comparison remains approximately the same whether we look at recent immigrants or immigrants overall, and at men or at women. (See Trejo and Funkhouser [1995], Simon and Akbari [1996], Schoeni [1998], and Cohen, Zach, and Chiswick [1997] for more on changes in immigrant characteristics.)

Interestingly, all four Censuses, spanning 30 years, show approximately the same rates of higher education for immigrants as for the native-born. The fraction with a college degree or above increased for all groups from 1960 to 1990 , but they are approximately the same for the native-born, immigrants, and recent immigrants within each year.

Perhaps the way in which immigrants changed the most over the three decades is in their racial and ethnic composition (Reimers 1981; Borjas 1991). In 1960, only $5 \%$ of the immigrant men and $7 \%$ of the recent immigrant men were Asian or "Other" race. ${ }^{6}$ By $1990,23 \%$ of immigrant and $27 \%$ of recent immigrant men were Asian. The changes in fraction Hispanic have also been dramatic. In $1970,22 \%$ of immigrant men were Hispanic. ${ }^{7}$ By 1990 , this number had approximately doubled to 45\%. The shifts are similar for women. These changes reflect the changes in the national origin mix of immigrants after the 1965 change in immigration laws (which was extended to include the Western Hemisphere in 1968 and thus took full effect sometime in the late 1960s). Prior to the 1965 change in the law, there was a quota system for visas, whereby the number of visas allocated to each country was based on the number of people of that origin already

\footnotetext{
${ }^{6}$ For 1960 and 1970 we combined Asian and "other

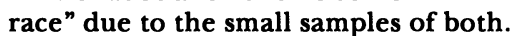

${ }^{7}$ For 1960 an individual is defined as "Hispanic" if he or she had a Spanish surname. This is not the same definition used in the other years, all of which use self-reported ethnicity information.
} 
residing in the United States. The 1965 law put heavy emphasis on family reunification, giving preference to those with a family member who was a U.S. citizen or permanent resident. ${ }^{8}$

Appendix Tables A1 and A2 also show the unadjusted log hourly wages for all groups in 1990 dollars. In 1960 and 1970, immigrant men and women both earned slightly more than their native-born counterparts. Immigrant men's wages fell steadily relative to those of the native-born between 1960 and 1990 . Whereas immigrant men in 1960 earned, on average, $5.3 \%$ more per hour than the native-born, by 1990 , they earned $9.5 \%$ less. For immigrant women, the story is a bit different. They earned about 2-3\% more than native women until 1990, when the wages of the two groups were approximately the same. ${ }^{9}$

Appendix Tables A1 and A2 also show the average hourly wages for recent immigrants in each year. Average hourly wages for recent immigrants have always been substantially lower than for the native-born. Recent immigrant men in 1960 and 1970 earned from $20 \%$ to $15 \%$ less per hour than native-born men. By 1990, this gap had climbed to $34 \%$ less. (See Borjas [1990] for similar figures.) The pattern for recent immigrant women is similar, but the levels are not: recent immigrant women earned about $14 \%$ less than native-born women in 1960 , and $19 \%$ less in 1990 .

Note that for both men and women, the recent immigrant/native-born wage differential was somewhat smaller in 1970 than in 1960. Recall that the changes in the immi-

\footnotetext{
${ }^{8}$ The 1965 law established two categories of immigrants: those with no numerical limitation, who include immediate relatives of U.S. citizens and refugees and asylees; and those who come under the 270,000 per year numerical limit, who fall into six preference categories based on their relationship to U.S. citizens and permanent residents, or on their skill set.

${ }^{9}$ This finding is similar to that for other comparisons of wages between ethnic groups; for example, the black-white wage gap is smaller for women than it is for men as well. See Blau and Beller (1992).
}

gration law that were passed in 1965 (and extended to the Western Hemisphere in 1968) almost certainly did not become fully effective until late in the 1960s. Moreover, available evidence suggests that income equality was closer to an all-time "high" in 1969 than at any other time in U.S. postwar history. ${ }^{10}$ For these reasons, we will conduct much of our analysis later in the paper using data on recent immigrants in 1970 .

This section has underscored two important patterns. First, immigrant women and men differ in their relative wages in the U.S. labor market. The gaps between the wages of immigrant and native-born women are substantially smaller than those between immigrant and native-born men, and do not follow the same trend. Little attention has been focused on the performance of the wages of immigrant women in the U.S. labor market. This omission is important to remedy because, in addition to being of substantive interest, analysis of the relative wages of women may shed light on theories about trends in the immigrant/native-born wage gap, which have been based exclusively on evidence from men (Borjas 1987). For example, consider the unadjusted immigrant/native-born log wage gaps shown in Table 1.

Although a complete analysis of the reasons for the gap should include an analysis of changes in labor force participation (see Schoeni 1998), a priori a single explanation based, say, on changes in immigration criteria and changes in sending regions does not readily explain the differences in the gaps.

Second, our results corroborate previous research on the decline in wage-earning attributes ("skills") of immigrants. In this section we focused on differences in mean log hourly wages and we found that immigrants, especially recent immigrants, in 1990 were earning substantially less than

\footnotetext{
${ }^{10}$ See, for example, the series on Gini indices in the P-60 Current Population Reports of the U.S. Bureau of the Census.
} 
Table 1. Unadjusted Immigrant/Native-Born Log Wage Gaps, 1960-1990.

\begin{tabular}{lccrr}
\hline Gender Group & 1960 & 1970 & 1980 & 1990 \\
\hline Men & -0.053 & -0.036 & 0.022 & 0.095 \\
Women & -0.023 & -0.033 & -0.035 & -0.005 \\
\hline
\end{tabular}

Note: Native less Immigrant Mean calculated from log wages reported in Appendix Tables A1 and A2.

their native-born counterparts, and this gap had increased over the previous 30 years. In what follows we analyze the role that changes in the distribution of earnings between 1960 and 1990 play in this decline in relative mean wages.

\section{Immigrant and Native Wage Distributions}

\section{General Considerations}

Up to this point, our focus has been on simple summaries of the data. Such approaches have many advantages, not least of which is a considerable amount of "data reduction": summarizing vast quantities of information compactly. On the other hand, some aspects of wage structure changes can be obscured by a focus on simple summary statistics. In this section, we again compare immigrant wages to native wages from our four Census samples, but this time with a focus on the entire distribution of wages.

\section{Methodological Concerns}

The non-parametric density estimates we consider in this paper use the kernel density estimator introduced by Rosenblatt (1956) and Parzen (1962). The kernel density estimate $\hat{f}_{h}$ of a univariate density $f$ based on a random sample $W_{1}, \ldots, W_{n}$ of size $n$, with weights $\theta_{1}, \ldots, \theta_{n}\left(\Sigma_{i} \theta_{i}=1\right)$, is

$$
\hat{f}_{h}(w)=\sum_{i=1}^{n} \frac{\theta_{i}}{h} K\left(\frac{w-W_{i}}{h}\right),
$$

where $h$ is the bandwidth and $\mathrm{K}($.$) is the$ kernel function. ${ }^{11}$

\footnotetext{
${ }^{11}$ In this section, the issue of weights is of little practical consequence, since only the 1990 Census
}

A potentially important issue in kernel density estimation is choice of bandwidth. Put simply, larger bandwidths result in more bias and less variance (over-smoothing), while smaller bandwidths result in less bias and more variance (under-smoothing). Although there are a number of different methods for automatically choosing the bandwidth ranging from cross-validation ${ }^{12}$ to "plug-in" methods, ${ }^{13}$ there is no consensus on what is "optimal." Instead, we apply a simple dictum: since it is generally easier to smooth with the eye than "unsmooth" with the eye, we choose bandwidths that err on the side of being "too small." Furthermore, when we consider more than one density estimate at a time, we apply the same bandwidth to each. The estimates in this section use bandwidths from 0.0477 to 0.0988, with smaller bandwidths for larger samples. As the general shape of the densities remains the same for a fairly large range of bandwidths, the issue of bandwidth seems to have little practical importance in our exercise.

Even less important is the issue of kernel choice. For all our estimates, we use a Gaussian kernel.

\section{Simple Density Estimates: All Immigrants and Natives}

In Figures $1 \mathrm{a}$ and $1 \mathrm{~b}$, we compare the density estimates for all immigrants and natives for 1960 through 1990 . We present

includes population weights. It will become a concern later when we consider "counterfactual" density estimates.

${ }^{12}$ See Silverman (1986) for a discussion.

${ }^{13}$ See Sheather and Jones (1991) for one example. 
Figure 1a. Density of Log Wages, Native Born vs. All Immigrants, 1960, 1970, 1980, and 1990: Men.
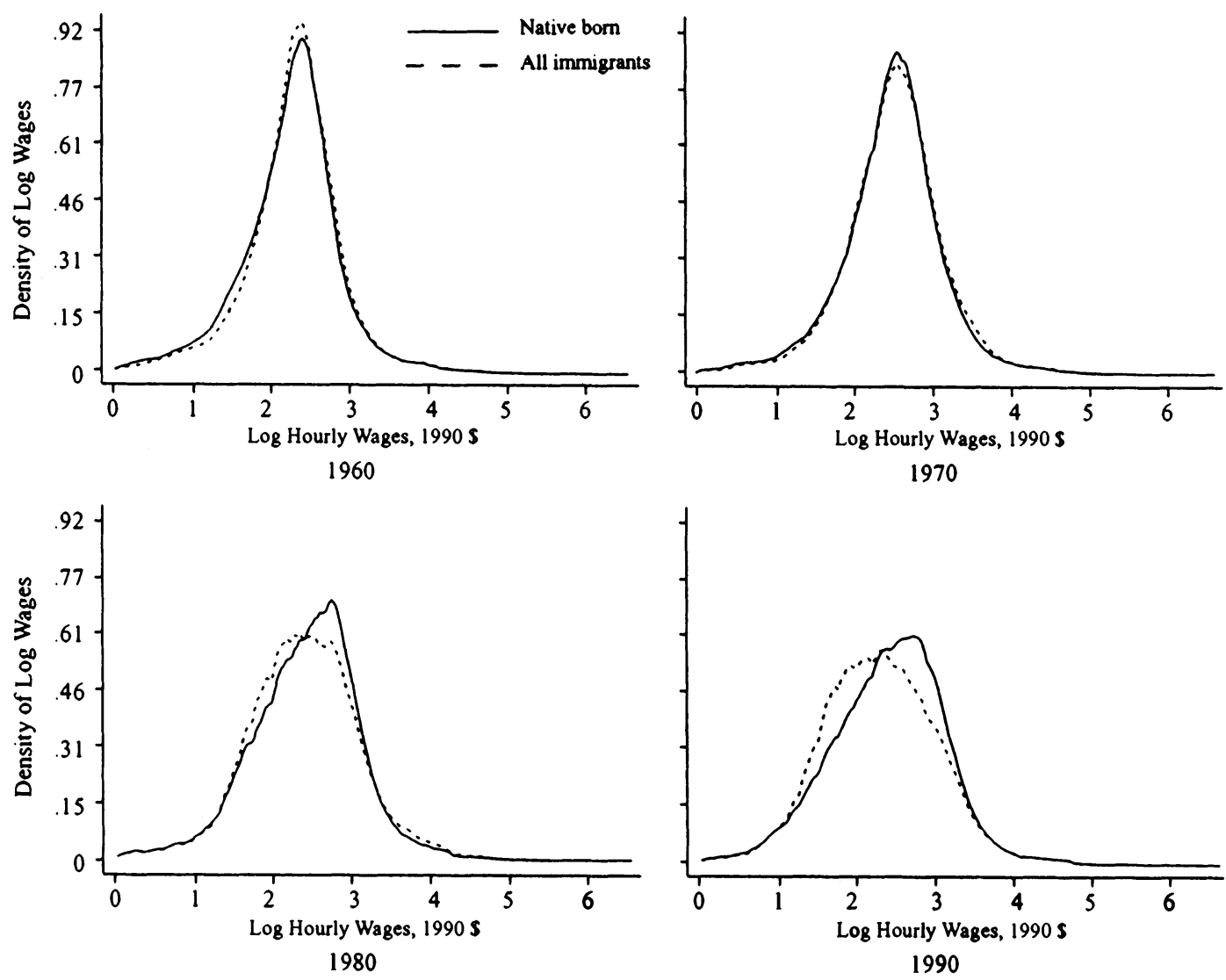

1970

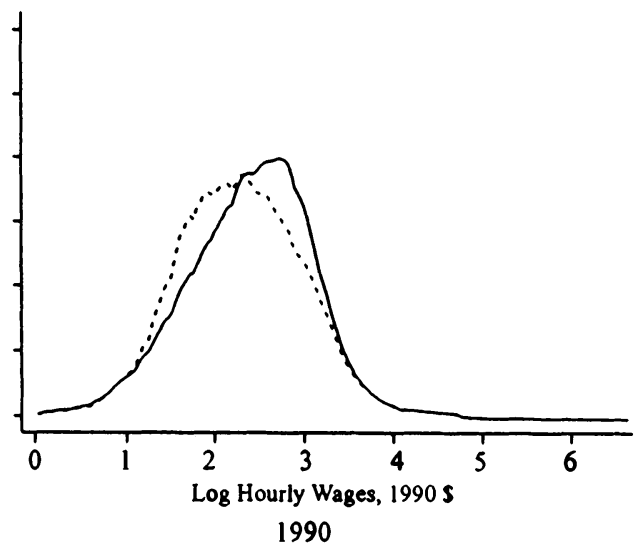

the densities for men and women separately. Log hourly wages have been converted to 1990 dollars.

Considering native men first, in our data real wages are generally increasing between 1960 and 1970 and decreasing thereafter. The distribution of immigrant wages shows some interesting patterns over time. In both 1960 and 1970, the immigrant and native-born wage distributions are very similar. After 1970 however, the two distributions begin to diverge. Much of the difference between the two distributions is slightly below and slightly above the median. The difference between the wage distributions of the two groups, in terms of measures such as mean wages, is less driven by differences at the extremes of the distributions than by differences between "middle-class" immigrants and natives (using the term middle-class in the sense of "middle portion of the distribution").

Again for women, in 1960 and 1970 the densities for immigrants are very similar to those for their native counterparts. However, the relative position of the two densities appears to converge in 1980 . Despite the measurement error in our constructed average hourly earnings measures, the large impact of the minimum wage (which in our sample period was at its most binding in 1979 ) is evident in the spike for both immigrants and natives in $1980 .{ }^{14}$ This is consis-

\footnotetext{
${ }^{14}$ In 1979 the minimum wage was $\$ 2.90$, or 1.61 in 1990 log dollars.
} 
Figure 1b. Density of Log Wages, Native Born vs. All Immigrants, 1960, 1970, 1980, and 1990: Women.
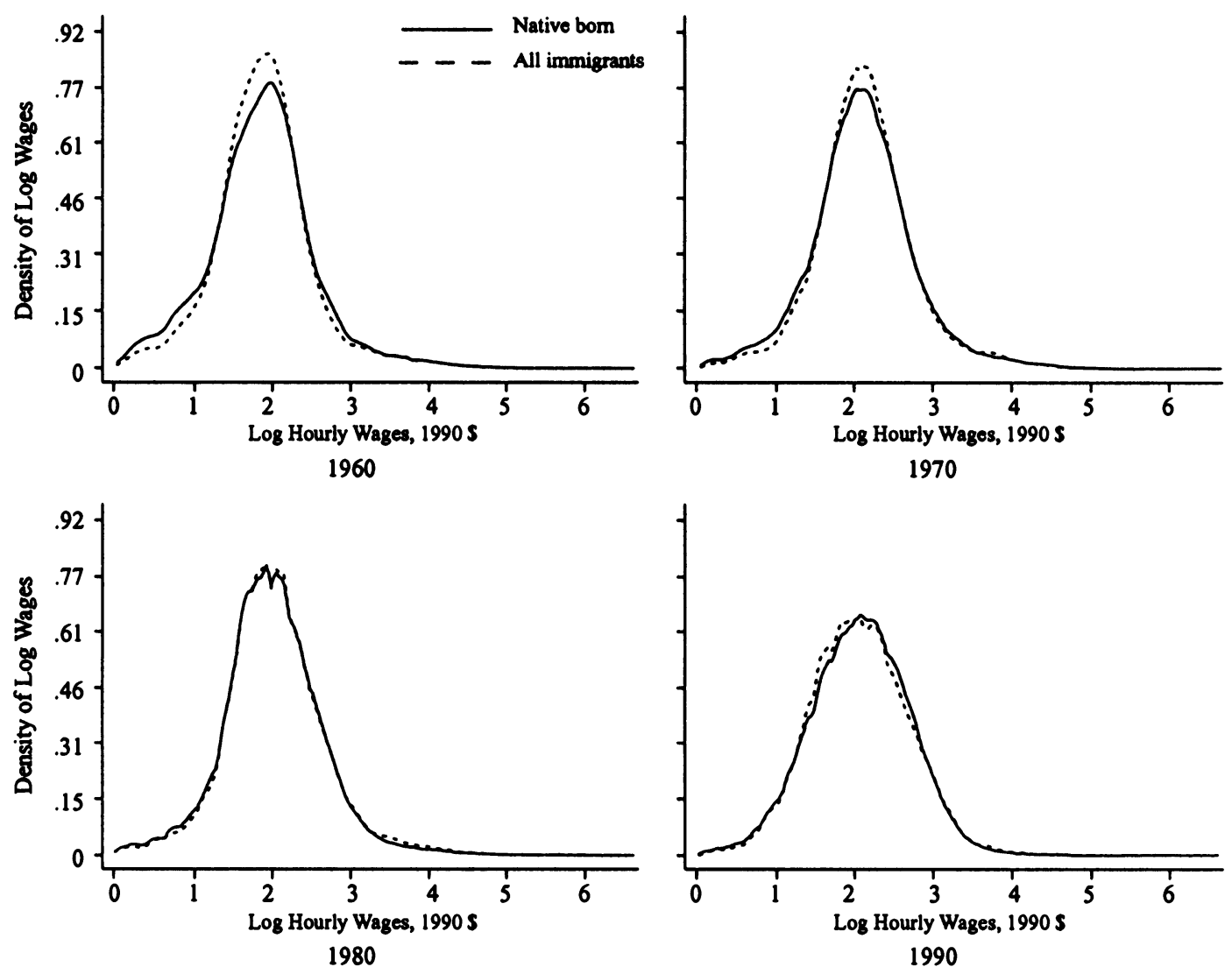

tent with the evidence presented in DiNardo, Fortin, and Lemieux (1996), and suggests that minimum wages cannot be ignored in a complete description of immigrant and native-born wage comparisons. Moreover, it suggests something other than changes in immigration policy as a (partial) source of the evolution of these gaps. By 1990, the distributions appear to begin to pull apart slightly, with immigrants relatively over-represented slightly to the left of mode and natives relatively over-represented slightly to the right of mode.

\section{Simple Density Estimates: Recent Immigrants and Natives}

We have thus far restricted our attention to a comparison between all immigrants and natives. In this subsection we consider the difference between recent immigrants and natives. In Figures $2 a$ and $2 b$ we therefore repeat the exercise we performed in the previous two figures, except this time we overlay the distribution of wages of recent immigrants and natives. As was mentioned earlier, a comparison of immigrants who have recently arrived (within the past five years in this analysis) is a direct way to investigate changes in immigrant skills across cohorts. The wages of immigrants overall are influenced by a myriad of factors, including the length of time the immigrants have been in the country, the size of the arriving cohort in each previous time period, and attrition of a cohort due to 
Figure 2a. Density of Log Wages, Native Born vs. Recent Immigrants, 1960, 1970, 1980, and 1990: Men.

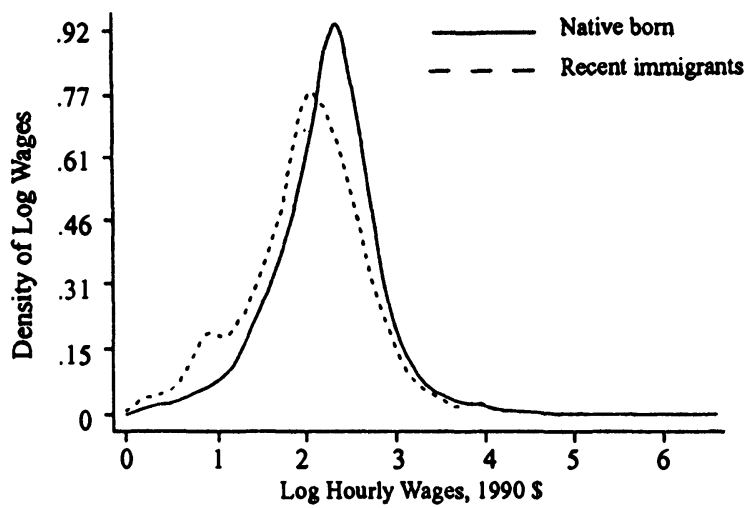

1960

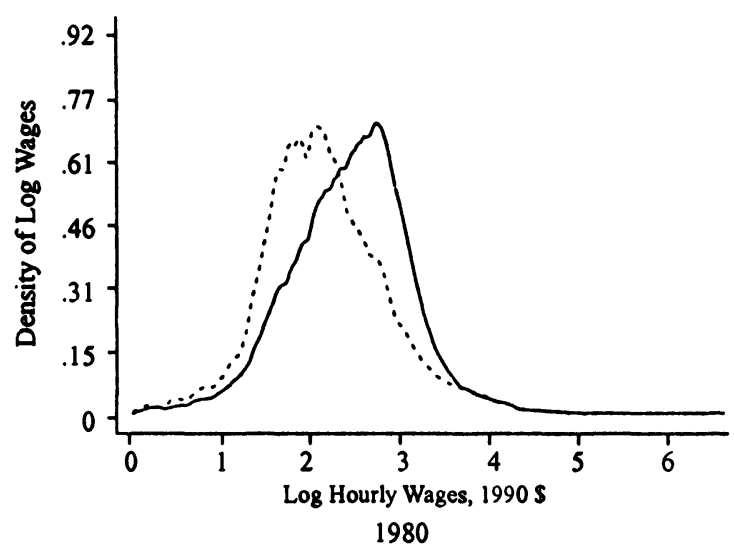

death and decisions to emigrate (Lubotsky 2000).

Men. The top two panels of Figure 2a display our estimates for our male 1960 and 1970 census samples. The bottom two panels display our estimates for 1980 and 1990. In contrast to Figure 1a, in which we considered all immigrant and native-born men, the leftward "shift" of the distribution of recent immigrant wages is quite pronounced. Inter alia, this is attributable to the fact that recent immigrants are much younger than natives taken as a whole, and are the youngest among all immigrants (see Appendix Table A1.)

One interesting way to describe the difference between the two male wage densi-

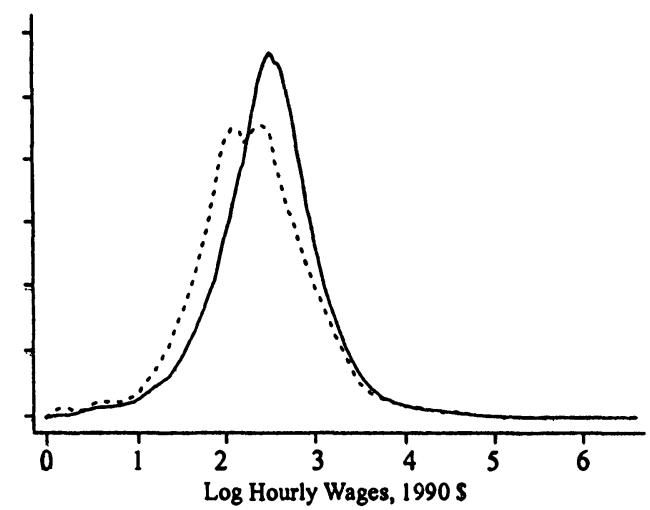

1970

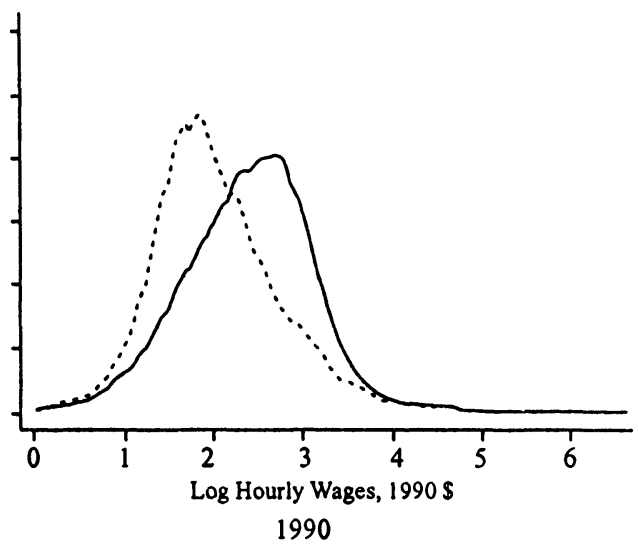

ties is to compare the wages of the modal recent immigrant and native. In 1960 the modal recent immigrant earned about $29 \%$ less than the modal native. In terms of magnitude, the big changes occurred after 1970. Between 1970 and 1980 the difference between the modal immigrant and his native counterpart rose 50 percentage points to $62 \%$ and then rose another 19 points. By 1990 , the modal recent immigrant was making $81 \%$ less than his native counterpart.

Women. In several respects, the changes in the relative distributions for women's wages are similar, but there is one noteworthy difference. The differences between the modal native and recent immigrant for the years 1960, 1970, 1980, and 1990 are 
Figure $2 b$. Density of Log Wages, Native Born vs. Recent Immigrants, 1960, 1970, 1980, and 1990: Women.
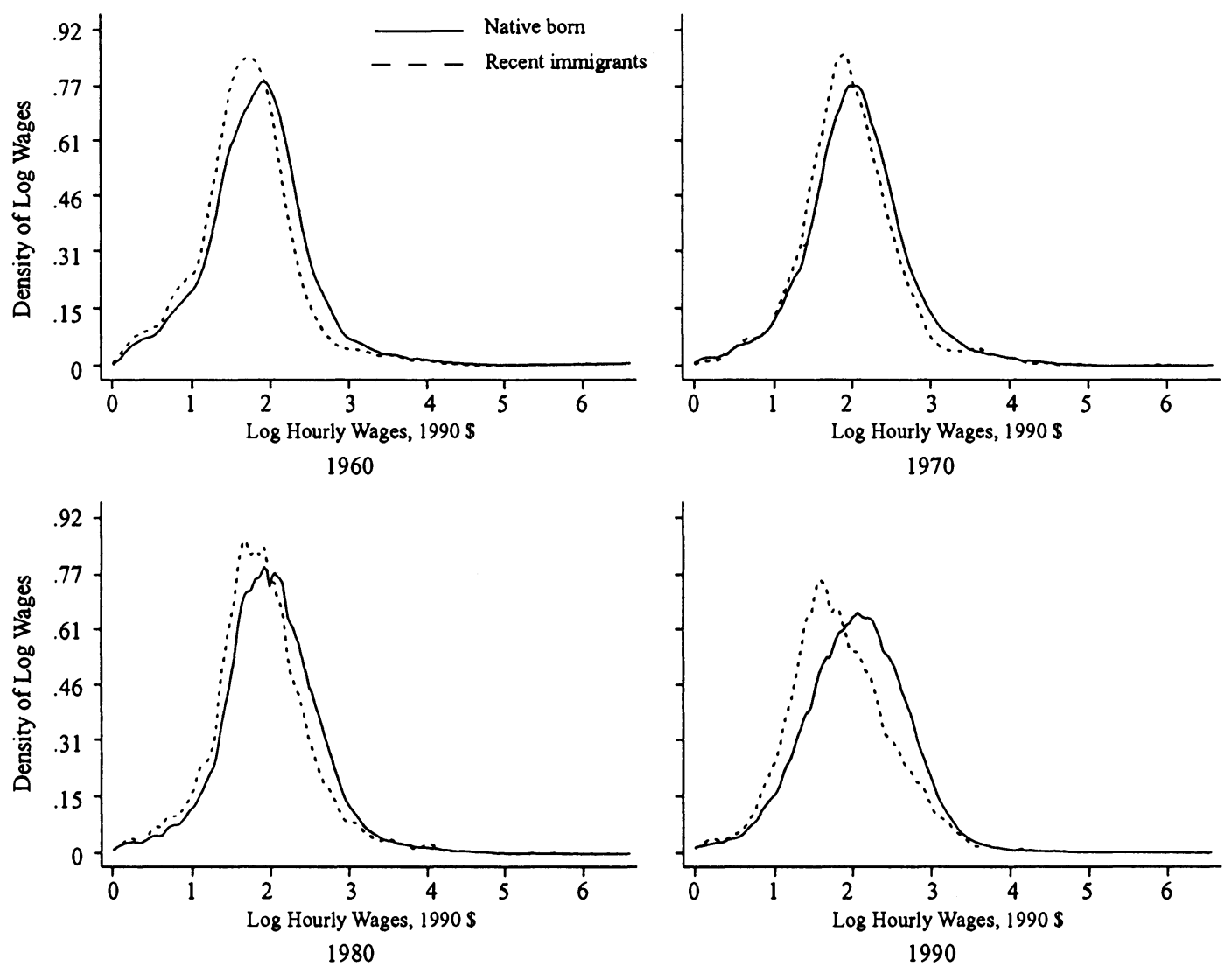

$0.20,0.07,0.23$, and 0.49 , respectively. The difference between men and women in the native/recent immigrant wage gap in 1980 is particularly noteworthy. Recall that the difference in modes between natives and recent immigrants was $62 \%$ for men in 1980 , compared to $23 \%$ for women. This is consistent with the evidence for women discussed above (under "Simple Density Estimates: All Immigrants and Natives"), which suggests the minimum wage played a large role in shaping the wage distribution for women. Evidence from the outgoing rotation group files of the CPS shows that wages at or very near the minimum wage represent the modal wage for all women (DiNardo, Fortin, and Lemieux 1996).

\section{Summary}

As noted earlier, although the big changes in immigration law were in effect for recent immigrants in 1980 and 1990, the summary statistics in Appendix Tables A1 and A2 do not tell a simple story about a uniform decline among immigrant women and men in the characteristics that are rewarded in the U.S. labor market. Rather, the visual evidence from the simple density functions is consistent with the important impact of the minimum wage, which is more binding for women than for men. This suggests that trends in the immigrant/native wage gap differ in ways directly attributable to changes in wage structure instead of changes in "skills." Any simple story about 
the changes in immigrant/native mean wages that relies solely on changes in admission criteria has difficulty encompassing the differences in results for men and women presented here.

\section{Counterfactual Density Estimates}

LaLonde and Topel (1992) discussed the role of the changing wage structure in comparisons between immigrants and the native-born. Although their analysis substantially differed from ours in form, they made a similar point. If immigrants have always been concentrated in the lower part of the earnings distribution, and the distribution of earnings becomes more dispersed, then immigrants' relative position will appear to have worsened, even without a change in their characteristics. Although immigrants overall are not concentrated in the very bottom of the distribution, LaLonde and Topel's emphasis on the importance of wage structure changes is consistent with our findings in the previous section. Additionally, since recent immigrants tend to be both much younger and in more disadvantaged ethnic/racial groups than natives and immigrants overall-a pattern that certainly held during the thirty years spanned by our study-they are more likely to be concentrated at the lower end of the earnings distribution in each year of our data (as seen in Figures $2 a$ and $2 b$ ). For this group, the changes in the wage structure are likely to be particularly important.

In this section we take the analysis one step further, by investigating how the earnings distribution for recent immigrants in the past would look if they faced the wage structure of the 1990s. Recall that the United States changed its immigration laws in 1965. These changes in criteria (and the shift in sending countries), which took effect in the late 1960s, are widely cited as a primary cause of the "deterioration" in the characteristics of immigrants. While recent immigrants in 1960 clearly had been admitted under the old criteria, most of the recent immigrants in 1970 had been admitted under the old criteria as well, since the law was not effective immediately. In addi- tion, the data in the 1970 Census, particularly those reflecting the operational definition of Hispanic, are more comparable with those in the 1980 and 1990 Census than are 1960 Census data. For these reasons, we will perform our comparisons in this section between recent immigrants in 1970 and recent immigrants in 1990 . However, we have completed all comparisons using the 1960 Census data as well, and these results are very similar.

\section{Methods}

In this section we consider the following thought experiment: what would the wage distribution of 1970 recent immigrants look like if those immigrants were treated (on the basis of observable X's only) as 1990 recent immigrants? To do this, we adapt methods used in DiNardo, Fortin, and Lemieux (1996). In what follows we briefly review the approach in this setting, and describe the necessary modifications. Additional detail can be found in DiNardo, Fortin, and Lemieux (1996).

One way to begin is to postulate two different wage equations, one for 1970 recent immigrants and another for 1990 recent immigrants:

$$
\begin{aligned}
& y^{70}=X^{70} \beta^{70}+\varepsilon^{70} \\
& y^{90}=X^{90} \beta^{90}+\varepsilon^{90}
\end{aligned}
$$

Given this formulation, the simplest way to proceed is to estimate separate regressions for the 1970 sample and the 1990 sample to get estimates of $\beta^{70}$ and $\beta^{90}$, respectively. The well-known Oaxaca (1973)/Blinder (1973) decomposition involves computation of

$$
\begin{gathered}
\widehat{Y_{70}^{90}}=\bar{X}_{70} \widehat{\beta^{90}} \\
\widehat{\bar{Y}_{90}^{70}}=\bar{X}_{90} \widehat{\beta^{70}},
\end{gathered}
$$

where $\widehat{\beta^{90}}$ and $\widehat{\beta^{70}}$ are the OLS estimates from equations (3) and (2), respectively, and $\bar{X}_{90}$ and $\bar{X}_{70}$ are the means of $X$ variables in 1990 and 1970 for recent immigrants. $\widehat{Y_{70}^{90}}$ is the mean salary of 1970 recent immigrant workers had they been paid with the 
wage function of recent immigrants in 1990. $\widehat{Y_{90}^{70}}$ is the mean salary of 1990 recent immigrants if they had been paid according to the wage function of 1970 recent immigrants.

In practical applications, the Oaxaca/ Blinder approach is generally restricted to a comparison of means. In fact, when the distributions one is comparing are unimodal and symmetric and have similar variances, the Oaxaca/Blinder approach comes quite close to being a "sufficient statistic" for the effect of changes in the structure of wages.

As has been well documented, changes in the shape of the distribution of wages over the time period we consider have been quite dramatic. With a simple modification of non-parame tric density estimation, however, it is easy to analyze such changes. One goal is to estimate the density that would have prevailed in 1990, had the distribution of wage-determining characteristics been as it was among 1970 recent immigrants.

Note that the overall distribution of wages yielded by the definition of conditional probability is

$$
g(w)=\int f(w \mid x) h(x) d x,
$$

where $f(w \mid x)$ is density of wages conditional on a set of characteristics $x$, which has a multivariate distribution with density $h(\cdot)$. Since the counterfactual distribution we wish to generate involves combining distributions with different "dates," it will be helpful to establish notation for the observed distributions that incorporate this dating.

Define the observed density of wages in 1990 as

$$
g(w \mid t=90)=\int f^{90}(w \mid x) h(x \mid t=90) d x,
$$

where $f^{90}(w \mid x) \equiv f(w \mid x, t=90)$. As before, in the special case where the conditional expectation and the linear projection are the same, $f^{90}(w \mid x)$ is closely related to the wage equation for recent immigrants in 1990 .

Likewise, the observed density of wages for recent immigrants in 1970 can be written as
(8) $g(w \mid t=70)=\int f^{70}(w \mid x) h(x \mid t=70) d x$, where $f^{70}(w \mid x) \equiv f(w \mid x, t=70)$.

We are interested in the distribution of wages if 1970 recent immigrants had been paid under the wage structure prevailing for recent immigrants in 1990, or, more formally,

$$
g_{70}^{90}(w)=\int f^{90}(w \mid x) h(x \mid t=70) d x .
$$

As it turns out, estimation of the above density can be simplified by resorting to Bayes Law, which implies that

$$
\begin{aligned}
& h(x)=\frac{h(x \mid t=70) \operatorname{Pr}(t=70)}{\operatorname{Pr}(t=70 \mid x)} \\
& h(x)=\frac{h(x \mid t=90) \operatorname{Pr}(t=90)}{\operatorname{Pr}(t=90 \mid x)} .
\end{aligned}
$$

Since we are in effect considering a sample of wage realizations from a "population" of 1970 and 1990 recent immigrants, we can without loss of generality set $\operatorname{Pr}(t=70)$ equal to $\operatorname{Pr}(t=90)$. That is, the cumulative probability of being a 1970 immigrant from this "population" is the same as the cumulative probability of being a $1990 \mathrm{immi}$ grant, and these two terms can be ignored in the analysis that follows.

Writing the above equations in terms of $h(x \mid t=70)$ and $h(x \mid t=90)$ reveals that equation (7) (that is, the actual density of 1990 recent immigrant wages) is exactly like the desired counterfactual distribution described in equation (9) except for the term $h(x \mid t=70)$, which is instead replaced by $h(x \mid t=90)$ in the actual 1990 distribution of wages.

This "problem" can be fixed by merely multiplying the "weight" in equation (7) by

$$
\frac{h(x \mid t=70)}{h(x \mid t=90)}
$$

Substituting equation (10) into equation (9) yields

$$
g_{70}^{90}(w)=\int \theta f^{90}(w \mid x) h(x \mid t=90) d x,
$$

where 


$$
\theta=\frac{\operatorname{Pr}(t=70 \mid x)}{\operatorname{Pr}(t=90 \mid x)} .
$$

But notice that equation (12) is identical to equation (7) except for the "weight" $\theta$. In essence, we have reduced the problem of estimating the desired counterfactual density to calculating the appropriate weight and applying this weight to the observed distribution of recent immigrant wages in 1990. The term $\operatorname{Pr}(t=70 \mid x)$ can be estimated non-parametrically, by dividing up the sample by the characteristics $x$ and calculating the proportion of individuals in each cell, or by a discrete choice model like the logit, where the $x$ 's are entered in a reasonably flexible way. We estimate $\theta$ by a simple logit of the form

$$
\begin{gathered}
\operatorname{Pr}(t=70)=\Lambda(f(\text { age } \\
\text { age squared, schooling, etc. }))
\end{gathered}
$$

with our combined sample of 1970 and 1990 immigrants. The choice of discrete model is of little consequence, but the logit has the practical advantage relative to the probit that the sum of predicted values equals the sum of empirically observed values. The resulting weights are then normalized to sum to one.

If the data are already weighted by some factor $\psi$ as in 1990 , this procedure is identical except that the weight is merely $\psi \cdot \theta$, where the weight is already normalized to sum to one.

Note that considering the entire distribution of wages does not preclude analyzing more conventional summaries of distributions. For instance, the weights we calculate can be used to compute any statistic of interest. Even the simple (mean) Oaxaca/Blinder counterfactual can be computed by taking the sample of 1990 immigrants and applying our counterfactual weights. ${ }^{15}$

\footnotetext{
${ }^{15}$ The Oaxaca/Blinder counterfactual computed the usual way takes a value almost identical to the Oaxaca/Blinder counterfactual using our weights.
}

\section{Results}

Our initial estimation equation included age, age squared, three schooling categories, three race and ethnicity categories, marital status, metropolitan residence, residence in a high immigrant state, seven industry dummies, five place of birth categories, and interactions between high immigrant state and some of the other variables, and between metropolitan area and some of the other variables. ${ }^{16}$ By including these variables, we are re-weighting the 1990 recent immigrants to have the same characteristics, as measured by these included variables, as the 1970 recent immigrants. We can also investigate the importance of these characteristics to our counterfactual density estimates by including or excluding them. A simple way to understand the effect of our choice of covariates on the estimates is again by analogy to the Blinder/ Oaxaca decomposition. If we omit a variable that is important to wages in our logit and whose distribution among the population in 1990 differs from its distribution in 1970 , this has the same effect as omitting

\footnotetext{
${ }^{16}$ Specifically, the estimation includes controls for living in a high immigrant state (dummy $=1$ if CA, FL, NY, TX, NJ, AZ); living in a metropolitan area; age; age $^{2}$; married; black, Hispanic, and other race; high school dropout; high school degree; some college; interactions between age and each of these education controls; controls for industry (agriculture, construction, durable manufacturing, non-durable manufacturing, retail, personal service, and professional service); controls for region of origin (Southeast Asia, Mexico, the Caribbean, Central America, and South America); interactions between high immigrant state and living in a metropolitan area; interactions between high immigrant state, metropolitan residence, and young (age less than 26); interactions between high immigrant state, metropolitan residence, and age; interactions between high immigrant state, metropolitan residence, the education categories, and age; interactions between high immigrant state, metropolitan residence, and each of the race/ethnicity variables; interactions between high immigrant state and marital status; interactions between metropolitan residence and marital status; and interactions between high immigrant state and each of the industry controls.
} 
the variable from the wage regression in the analogous Blinder/Oaxaca analysis.

The most discussed changes in immigrants' characteristics are the changes in education, race and ethnicity, and region of birth. Our first set of counterfactual density estimates includes the full set of variables listed above. We then show the importance of race and ethnicity and region of origin to the changes in recent immigrant wages between 1970 and 1990.

Figure 3 presents our counterfactual density estimates. Each picture overlays two densities: the actual estimated density for recent immigrants in 1990, and our estimate of the distribution of wages that would have obtained for 1970 immigrants if they had faced 1990 skill prices constructed as described in the previous subsection. The left panel is for recent immigrant women, and the right panel for men.

The first set of pictures shows the results when we include all of the characteristics described above. For both women and men, the "actual" density is somewhat leftshifted compared to the "counterfactual" density, but there is substantial overlap. The overlap is greater for women than for men. ${ }^{17}$ This overlap suggests that even if 1990 recent immigrants had characteristics identical to those of immigrants who arrived in 1970, we would still see a decline in the earnings of recent immigrants. The most notable difference between these densities, however, is in the dispersion. If recent immigrant men from the 1970s had faced the skill prices prevailing in 1990, the distribution of their wages would have been much more dispersed than it actually is among the 1990 recent immigrant men.

The results for women in the top panel show substantial overlap between the actual and counterfactual densities. The counterfactual density shows somewhat

\footnotetext{
${ }^{17}$ The minor differences between the "actual" densities here and in Figures $2 \mathrm{a}$ and $2 \mathrm{~b}$ are due to differences in smoothing: the bandwidth for the actual densities in Figure 3 was chosen to be the same as those for the counterfactuals in Figure 3.
}

higher concentrations to right of the mode than the actual density does. Again, this suggests that if recent immigrant women in 1990 had instead had the characteristics of recent immigrant women in 1970, we would nonetheless observe virtually the identical wage distribution.

Our next idea explores the question: which characteristics most distinguish (in terms of their "effect" on wages) the recent immigrants of the 1970s and the 1990s? The immigrant characteristics that receive the most attention in popular discussion are education, race and ethnicity, and region of origin. We will use our techniques to investigate the sensitivity of our counterfactual estimates to the exclusion of race/ethnicity and region of origin variables. We approach this question agnostic on the precise mechanism by which demographic variables have measurable effects on wages. Current practice is to assume that wages largely reflect marginal productivity and that variables correlated with wages do so because they are correlated with productivity, despite potential difficulties with such an approach (DiNardo and Pischke 1997). Absent direct evidence on marginal productivity, we think a satisfactory resolution of this debate is unlikely to occur soon.

We first investigate the sensitivity of these estimates to race and ethnicity changes. The second panel in Figure 3 shows the result of excluding race and ethnicity from the logit used to predict whether one is a 1970 or 1990 immigrant. Thus, education, state of residence, industry, and region of birth are the important predictors of whether one is a 1970 or 1990 recent immigrant. By excluding race and ethnicity, we are asking how the wages of individuals who look like the 1970 recent immigrants except for their racial and ethnic composition compare to the wages of 1990 recent immigrants, when faced with the 1990 wage structure. Again, this is roughly analogous to dropping the race/ethnicity variables from a Oaxaca/Blinder-type decomposition.

The results in the second panel show the tremendous importance of race and ethnicity in determining the changes in 

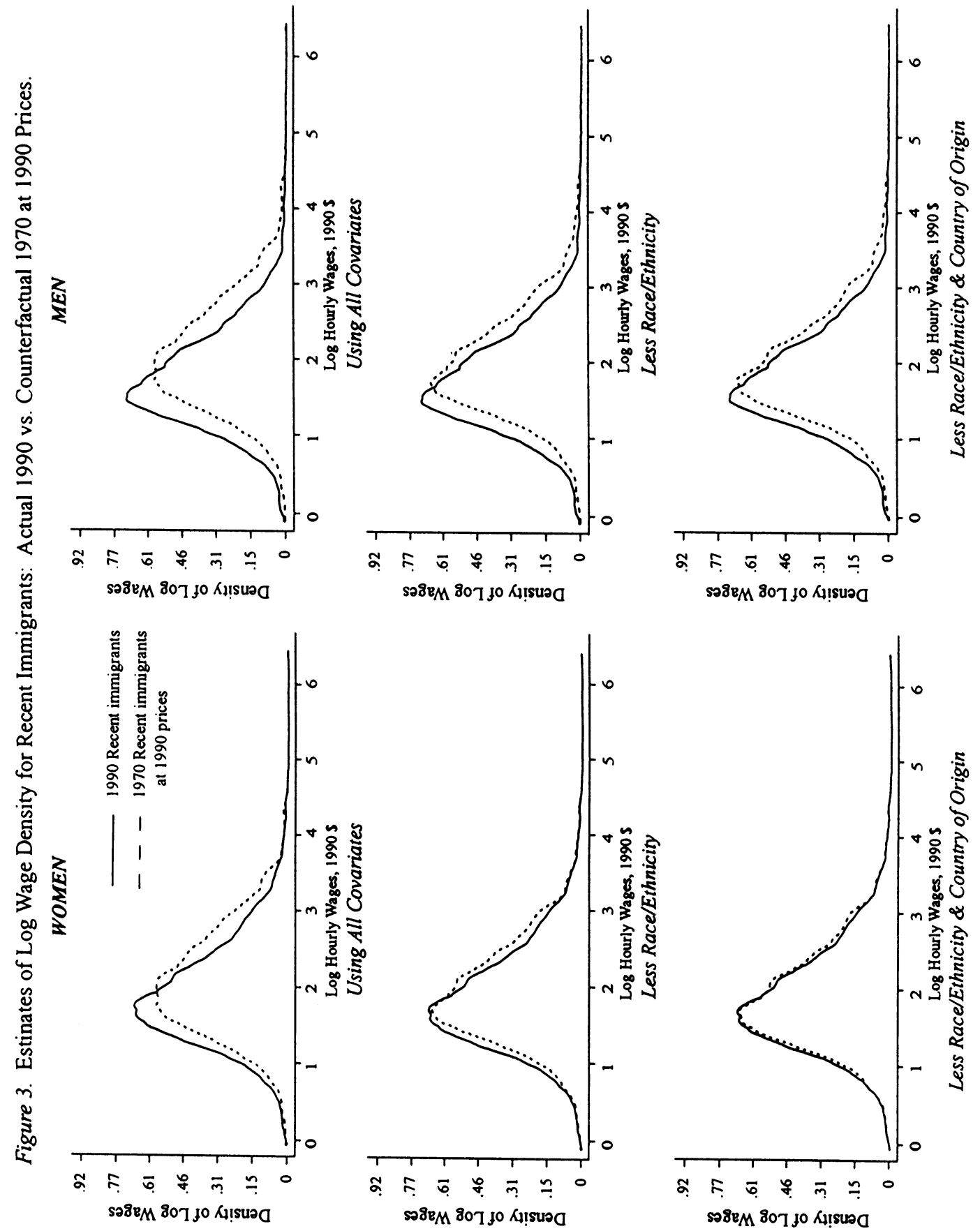
wages between 1970 and 1990 . Once these characteristics are no longer included, the differences in the actual and counterfactual densities diminish. This is especially the case for women.

In the above exercise, region of origin is included in the prediction equation. ${ }^{18}$ Since region of birth and race and ethnicity are closely related, these might be quite similar exercises. The last set of results further excludes these five region of birth categories from the prediction equation. We see that the differences between the actual and counterfactual distributions shrink even more.

This exercise demonstrates that there is a very large overlap between the wages of recent immigrants in 1990 and the wages recent immigrants in 1970 would have received had they faced the 1990 prices for their skills or characteristics. To the extent that there are differences between the actual and counterfactual densities, they appear to be related to the race and ethnicity changes in recent immigrants between 1970 and 1990. When we discriminate between recent immigrants based neither on race/ ethnicity nor on region of origin, all differences disappear.

\section{Changes in the Wage Structure or Changes in Immigrant Skills?}

In this section we decompose the change in the gap in wages between recent immigrants and the native-born into a portion due to changes in the wage structure and a portion due to changes in relative skills. Adapting the weights constructed in the previous section allows us to perform this decomposition at different points in the wage distribution. In this section, we use the most complete set of observable "skills"-including race/ethnicity and region of birth for the recent immigrants-to characterize the changes in the attributes that affect wages.

\footnotetext{
${ }^{18}$ The five regions of birth are Southeast Asia, Mexico, Central America, South America, and the Caribbean.
}

One important point we make in this section is that any Blinder/Oaxaca decomposition of differentials into "wage structure" versus "skills" is not unique, for reasons stressed in the original literature on the subject.

Simply put, when the wage structure has been changing a great deal, it must play an important role in any "gap." This is well recognized in the Blinder/Oaxaca discrimination literature. The extent of discrimination against women, for example, will differ depending on whether the women's coefficients or "prices" are used, as in

$$
\left(\bar{X}_{m}-\bar{X}_{w}\right) \beta_{w} \text {, }
$$

or men's coefficients or "prices" are used, as in

$$
\left(\bar{X}_{m}-\bar{X}_{w}\right) \beta_{m}
$$

where in the usual notation $\bar{X}_{w}$ represents the average value of the wage-determining characteristics for women, $\beta_{w}$ represents the coefficients from a wage regression using only women, and the remaining terms are defined analogously for men.

A similar point applies with equal force to immigrant/native wage differential decompositions, as has been stressed by LaLonde and Topel (1992). It will be useful to establish some notation. The change in the wage gap $(\Delta G)$ can be written as

$$
\left(N_{90}^{90}-I_{90}^{90}\right)-\left(N_{70}^{70}-I_{70}^{70}\right)=\Delta G,
$$

where $N_{x}^{y}$ refers to the mean (or other moment) of native-born wages with skills as in year $x$ and wage structure as in year $y$ and $I_{x}^{y}$ is defined analogously for immigrants. Ûsing the weights from a logit as before, the appropriate moment is straightforward to compute. ${ }^{19}$ The top panels of Tables $2 \mathrm{a}$ and $2 \mathrm{~b}$ report all the possible permutations

\footnotetext{
${ }^{19}$ This requires running a logit to predict who is a 1970 native, in order to construct weights analogous to those described above for the native-born. We use the same explanatory variables, except for region of birth.
} 
Table 2a. Native-Born and Recent Immigrant Log Wages Evaluated at Skill Prices and Characteristics from 1970 to 1990: Men.

\begin{tabular}{|c|c|c|c|c|c|c|c|c|}
\hline \multirow[b]{2}{*}{ Percentile } & \multicolumn{4}{|c|}{ Native Born } & \multicolumn{4}{|c|}{ Recent Immigrants } \\
\hline & $\begin{array}{c}\text { ‘90 Prices } \\
\text { '90 X's } \\
N_{90}^{90}\end{array}$ & $\begin{array}{c}\text { '70 Prices } \\
\text { '70 X's } \\
N_{70}^{70} \\
\end{array}$ & $\begin{array}{c}\text { ‘9 Prices } \\
\text { '70 X's } \\
N_{70}^{90} \\
\end{array}$ & $\begin{array}{c}\text { ‘70 Prices } \\
\text { ‘90 X's } \\
N_{90}^{70}\end{array}$ & $\begin{array}{c}\text { ‘90 Prices } \\
\text { ‘90 X's } \\
I_{90}^{90} \\
\end{array}$ & $\begin{array}{c}\text { '70 Prices } \\
\text { '70 X's } \\
I_{70}^{70} \\
\end{array}$ & $\begin{array}{c}90 \text { Prices } \\
\text { '70 X's } \\
I^{90} \\
70 \\
\end{array}$ & $\begin{array}{c}\text { '70 Prices } \\
\text { '90 X's } \\
I_{90}^{70} \\
\end{array}$ \\
\hline 25th Percentile & 1.879 & 2.120 & 1.878 & 2.166 & 1.534 & 1.904 & 1.668 & 1.866 \\
\hline 50th Percentile & 2.377 & 2.488 & 2.337 & 2.538 & 1.906 & 2.287 & 2.101 & 2.270 \\
\hline 75th Percentile & 2.807 & 2.796 & 2.733 & 2.902 & 2.377 & 2.690 & 2.621 & 2.692 \\
\hline $\begin{array}{l}\text { Mean } \\
\text { (Std. Dev.) }\end{array}$ & $\begin{array}{c}2.337 \\
(0.719)\end{array}$ & $\begin{array}{c}2.447 \\
(0.646)\end{array}$ & $\begin{array}{c}2.300 \\
(0.685)\end{array}$ & $\begin{array}{c}2.517 \\
(0.688)\end{array}$ & $\begin{array}{c}1.995 \\
(0.725)\end{array}$ & $\begin{array}{c}2.293 \\
(0.701)\end{array}$ & $\begin{array}{c}2.170 \\
(0.737)\end{array}$ & $\begin{array}{c}2.271 \\
(0.745)\end{array}$ \\
\hline Obs. & 675,249 & 362,864 & 675,249 & 362,864 & 15,154 & 4,014 & 15,154 & 4,014 \\
\hline
\end{tabular}

\begin{tabular}{lcc}
\hline & 1990 Skill Prices & $\begin{array}{c}1970 \text { Skill Prices } \\
\left(N_{90}^{90}-I_{90}^{90}\right)-\left(N_{70}^{90}-I_{70}^{90}\right)\end{array}$ \\
\hline 25th Percentile & 0.135 & 0.084 \\
50th Percentile & 0.235 & 0.067 \\
75 th Percentile & 0.318 & 0.104 \\
Mean & 0.212 & 0.092 \\
\hline
\end{tabular}

Notes: These numbers were calculated using the 1970 and 1990 PUMS of the U.S. Census. In the top panel, the columns with 1990 prices and $1990 X$ s are simply the log wages for 1990 . Columns with 1990 Prices and $1970 X$ 's are calculated by re-weighting the 1990 individuals to have the same characteristics as the 1970 individuals. Other columns are defined analogously. The bottom panel calculates changes in the native-born/recent immigrant wage gap. In both cases, the changes in characteristics are the actual changes between 1970 and 1990. These changes in characteristics are evaluated at the skill price distribution in 1990 in the first column, and the skill price distribution in 1970 in the second column. In the equations above, the superscript denotes the skill prices and the subscript denotes the characteristics. See the text for a more detailed explanation. 
of $N_{x}^{y}$ and $I_{x}^{y}$ for different moments of the distribution. In what follows, we will use the elements of the top panel to demonstrate how evaluations of the importance of wage structure changes are sensitive to essentially arbitrary assumptions about the price of skill.

Note that equation (17) can be rewritten as

$$
\begin{gathered}
{\left[\left(N_{90}^{90}-N_{70}^{90}\right)-\left(I_{90}^{90}-I_{70}^{90}\right)\right]} \\
+\left[\left(N_{70}^{90}-N_{70}^{70}\right)-\left(I_{70}^{90}-I_{70}^{70}\right)\right]=\Delta G,
\end{gathered}
$$

where we have merely added and subtracted the term $N_{70}^{90}-I_{70}^{90}$. The first term in brackets may be described as the change in the wage gap attributable to the change in the native-born/immigrant gap in "skills." More precisely, it is the change in the gap that would have occurred had 1990 skill prices prevailed over the entire period.

The second term in brackets may be described as the change in the gap attributable to changes in the wage structure. This part of the gap is merely the change in the native-born/immigrant wage gap that would have occurred if neither group had experienced a change in their $X$ variables. Put differently, it is the change in the value of the skill gap between immigrants and natives that existed in 1970 .

In 1990, the gap between recent immigrant men and the native-born men (at the mean) was $34 \%$. In 1970 , this gap was only $15 \%$, which implies that the gap increased 19 percentage points over the period 197090 . In the first column of the lower panel of Table $2 \mathrm{a}$, we present the amount of the gap that is attributable to "skills" as in the decomposition in equation (18). At the mean (the last row of the table), the change in the wage gap over the period 1970-90 that is attributable to the relatively lower "skills" of recent immigrants is $21 \%$, which explains more than $100 \%$ of the difference. Like most other analyses, this evidence might lead one to conclude that "changes in the U.S. wage structure were not sufficiently large to account for a sizable part of the declining relative wage of immigrants" (Borjas 1994).

It is evident, however, that this is not the only way to do such a decomposition. Suppose instead that we add and subtract the term $N_{90}^{70}-I_{90}^{70}$. Doing so yields

$$
\begin{gathered}
{\left[\left(N_{90}^{90}-N_{90}^{70}\right)-\left(I_{90}^{90}-I_{90}^{70}\right)\right]} \\
+\left[\left(N_{90}^{70}-N_{70}^{70}\right)-\left(I_{90}^{70}-I_{70}^{70}\right)\right]=\Delta G .
\end{gathered}
$$

In this case, the first term in brackets could be labeled the part of $\Delta G$ attributable to changes in the wage structure: that is, it measures how the gap would have changed if the skills of immigrants and natives had always been at their 1990 level. The second term could be labeled the part of the gap attributable to the change in skills, although in contrast to the previous decomposition we evaluate the change in skills in 1970 s prices instead of 1990 s prices. It might be helpful to view this decomposition as identical to the previous case, except that we have reversed the roles of 1990 and 1970 .

This "role reversal" has quite important implications for evaluating the importance of the wage structure in the increasing wage gap between recent immigrants and the native-born. Consider the bottom panel of Table 2a. The second column shows that for men, at the mean, had the wage structure remained as it was in 1970 , the increase in the wage gap would have been only 9.2 percentage points. As the actual wage gap increased 18.8 percentage points, more than $50 \%$ of the increase is now attributable to the wage structure.

Depending on where in the wage distribution one looks, the effects can be even more dramatic. Consider the 75 th percentile of the male wage distribution. Over the 1970-90 period, the wage gap increased from $10.6 \%$ to $43 \%$. Evaluating the increase in the skill gap at 1970 skill prices yields only $10.4 \%$. Using this particular decomposition, therefore, wage structure changes explain $68 \%$ of the increase in the wage gap.

We should stress, however, that there is nothing unique about our sample that leads to the conclusion that wage structure changes are important. Using the decomposition given by equation (18), virtually all of the increase in the recent immigrant native-born wage differential can be attrib- 
Table 2b. Native-Born and Recent Immigrant Log Wages Evaluated at Skill Prices and Characteristics from 1970 to 1990 : Women.

\begin{tabular}{|c|c|c|c|c|c|c|c|c|}
\hline \multirow[b]{2}{*}{ Percentile } & \multicolumn{4}{|c|}{ Native Born } & \multicolumn{4}{|c|}{ Recent Immigrants } \\
\hline & $\begin{array}{c}\text { '90 Prices } \\
\text { '90 X's } \\
N_{90}^{90}\end{array}$ & $\begin{array}{c}\text { '70 Prices } \\
\text { '70 X's } \\
N_{70}^{70}\end{array}$ & $\begin{array}{c}\text { ‘90 Prices } \\
\text { '70 X's } \\
N_{70}^{90} \\
\end{array}$ & $\begin{array}{c}\text { '70 Prices } \\
\text { '90 X's } \\
N_{90}^{70}\end{array}$ & $\begin{array}{c}\text { '90 Prices } \\
\text { '90 X's } \\
I_{90}^{90} \\
\end{array}$ & $\begin{array}{c}\text { '70 Prices } \\
\text { '70 X's } \\
I_{70}^{70} \\
\end{array}$ & $\begin{array}{c}\text { ‘90 Prices } \\
\text { '70 X's } \\
I_{70}^{90} \\
\end{array}$ & $\begin{array}{c}\text { '70 Prices } \\
\text { '90 X's } \\
I_{90}^{70} \\
\end{array}$ \\
\hline 25 th percentile & 1.609 & 1.677 & 1.504 & 1.788 & 1.419 & 1.599 & 1.427 & 1.572 \\
\hline 50 th percentile & 2.040 & 2.049 & 1.907 & 2.166 & 1.781 & 1.933 & 1.783 & 1.991 \\
\hline 75th percentile & 2.474 & 2.407 & 2.303 & 2.543 & 2.238 & 2.289 & 2.238 & 2.337 \\
\hline $\begin{array}{l}\text { Mean } \\
\text { (Std. Dev.) }\end{array}$ & $\begin{array}{c}2.042 \\
(0.662)\end{array}$ & $\begin{array}{c}2.048 \\
(0.686)\end{array}$ & $\begin{array}{c}1.916 \\
(0.648)\end{array}$ & $\begin{array}{c}2.179 \\
(0.700)\end{array}$ & $\begin{array}{c}1.849 \\
(0.679)\end{array}$ & $\begin{array}{c}1.974 \\
(0.670)\end{array}$ & $\begin{array}{c}1.849 \\
(0.639)\end{array}$ & $\begin{array}{c}1.985 \\
(0.716)\end{array}$ \\
\hline \multirow[t]{3}{*}{ Obs. } & 624,373 & 226,994 & 624,373 & 226,994 & 9,410 & 2,625 & 9,410 & 2,625 \\
\hline & \multicolumn{8}{|c|}{ hanges in the Native/Recent Immigrant Wage Gap Evaluated at 1990 and 1970 Skill Prices } \\
\hline & \multicolumn{4}{|c|}{$\begin{array}{c}1990 \text { Skill Prices } \\
\left(N_{90}^{90}-I_{90}^{90}\right)-\left(N_{70}^{90}-I_{70}^{90}\right) \\
\end{array}$} & \multicolumn{4}{|c|}{$\begin{array}{c}1970 \text { Skill Prices } \\
\left(N_{90}^{70}-I_{90}^{70}\right)-\left(N_{70}^{70}-I_{70}^{70}\right)\end{array}$} \\
\hline 25th percentile & \multicolumn{4}{|c|}{0.113} & \multicolumn{4}{|c|}{0.138} \\
\hline 50th percentile & \multicolumn{4}{|c|}{0.135} & \multicolumn{4}{|c|}{0.059} \\
\hline 75th percentile & \multicolumn{4}{|c|}{0.171} & \multicolumn{4}{|c|}{0.088} \\
\hline Mean & \multicolumn{4}{|c|}{0.126} & \multicolumn{4}{|c|}{0.120} \\
\hline
\end{tabular}

Notes: See Table 2a. 
uted to "skill." If we evaluate the change in skill in 1990 prices, the gap at the respective 75 th percentiles would have been $31.8 \%$. As the actual gap was $32.4 \%$, this decomposition suggests the changing skill gap explains almost $98 \%$ of the increase in the native-born/recent immigrant wage differential!

The sensitivity of the decomposition to the choice of base period is also evident in the results for women, displayed in Table $2 \mathrm{~b}$. At the 50 th and 75 th percentiles, the change in the gap due to skills is twice as large when it is evaluated at 1990 prices (equation 18) as when it is evaluated at 1970 prices (equation 19). Interestingly, at the 25 th percentile the proportion attributable to skill is larger when evaluated at 1970 prices (13.8) than when evaluated at 1990 prices (11.3).

It may be helpful at this point to compare our results with related work. LaLonde and Topel (1992), among others, have observed that wage structure changes cannot be ignored in analyses of immigrant/native-born wage differentials. Borjas (1995) investigated the role played by wage structure changes in immigrant/native relative wages using two separate "deflators" to account for changes in the prices of skills. The first method computes mean log wages for native workers within age-education cells for each census year. The difference between the cell mean in a given census year and in 1970 is used as the deflator. The second method (originally suggested by LaLonde and Topel) is to calculate a "percentile deflator" by assigning immigrants to their rank - the average immigrant falls in the $\mathrm{p}^{\text {th }}$ percentile-in the native-born wage distribution. This method then uses the change in wage for the $\mathrm{p}^{\text {th }}$ percentile of the native-born wage distribution between two census years as the deflator.

As Borjas noted, each of these methods of "netting out" the effect of wage structure has problems. A significant limitation of the age-education "deflator" is that it ignores within-cell variation-an important source of changes in the wage structure identified by Katz and Murphy (1992) and others. One advantage of the methods used in this paper is that such variation is not ignored.

While the percentile deflator does not ignore within-group variation in wages, Borjas (1995) pointed out that it assumes that immigrants and natives within a given percentile of the wage distribution are equally skilled. Such an assumption would be violated, for example, if assimilation is important-an immigrant to this country who begins at the $\mathrm{p}^{\text {th }}$ percentile of the wage distribution may find him/herself in the $p$ $+q^{\text {th }}$ part of the skill distribution after having had time to "adjust" to the U.S. labor market. Another case in which the assumption might be violated is when wage determination depends on more than one "factor" or "skill." For instance, if there are two factors that determine wages, and these two factors have different prices that evolve differently over time, then percentile rankings in the wage distribution are not sufficient to rank the "skill" of a wage earner. ${ }^{20}$

While we (partially) sidestep the aforementioned "assimilation" issue by our focus on recent immigrants, our method is not a silver bullet, and it suffers from all the limitations inherent in a standard Blinder/ Oaxaca framework-the sensitivity of the results to differences in unobserved factors, misspecification, and so on. There is nothing, however, unique about our sample that leads to the conclusion that wage structure changes are important. Indeed, our estimates of the unadjusted wage gap between recent immigrants and the nativeborn are almost identical to those reported in Borjas's (1995) Table 1, for example. However, a maintained assumption in our analysis is that our covariates are sufficient to characterize wage determination.

\footnotetext{
${ }^{20}$ Indeed, while sufficient for many purposes, formal tests of the "single factor model" often reject the adequacy of a single factor to describe U.S. wage determination. See Card and Lemieux (1996), Chay and Lee (1996), and Deschênes (2001), for example. For a good discussion with an explicit focus on immigrants and natives, see Lubotsky (2001).
} 
More recently, Lubotsky (2001), using data on all immigrants, arrived at similar conclusions about the importance of wage structure changes in estimates of the "skill gap." While adopting the single-factor index model restrictions (which, however, allow wages to depend on unobservable skill), he used longitudinal earnings data on immigrants to estimate a genuine "assimilation" profile. He found, for example, that if the price of skill had remained at its 1980 level, the immigrant/native-born wage gap would have been 6 to 15 percentage points lower in 1997.

\section{Summary and Conclusion}

Two broad results of our analysis stand out:

1. Patterns of comparison between the wages of immigrants and the native-born are not the same for men and women. Furthermore, these differences highlight the importance of the evolution of the wage structure in immigrant/native-born wage comparisons. For example, the minimum wage appears to exert a greater effect on the wage distribu- tion for women than for men.

2. The wage distribution that results from the 1990 wage structure and the 1970 distribution of schooling, potential experience, geographic distribution, industry, race, ethnicity, country of origin, etc. is markedly similar to the wage distribution that prevailed for recent immigrants in 1990. Moreover, without the use of race/ethnicity or region of origin as covariates, the similarities are more striking: the actual and counterfactual wage distributions are very similar for men, and virtually identical for women.

These results lead us to conclude, with Lubotsky (2001), that wage structure changes are an important part of the explanation for changes in the immigrant/native-born wage gap. The dramatic changes in the distribution of wages between 1960 and 1990 appear to have had an important effect on the relative wages of immigrants and the native-born. One implication is that the emphasis on post-1965 changes in United States immigration policy in explaining the relative wages of immigrants and natives may be misplaced. 
Appendix Table Al

Descriptive Statistics for Men: Native-Born, Immigrants, and Recent Immigrants, by Year (Standard Errors in Parentheses)

\begin{tabular}{|c|c|c|c|c|c|c|}
\hline \multirow[b]{2}{*}{ Variable Name } & \multicolumn{3}{|c|}{1960} & \multicolumn{3}{|c|}{1970} \\
\hline & Native-Born & Immigrants & $\begin{array}{c}\text { Recent } \\
\text { Immigrants }\end{array}$ & Native-Born & Immigrants & $\begin{array}{c}\text { Recent } \\
\text { Immigrants }\end{array}$ \\
\hline Age & $\begin{array}{l}37.913 \\
(0.0196)\end{array}$ & $\begin{array}{l}47.752 \\
(0.0765)\end{array}$ & $\begin{array}{l}33.059 \\
(0.1797)\end{array}$ & $\begin{array}{l}37.189 \\
(0.0190)\end{array}$ & $\begin{array}{l}41.746 \\
(0.0885)\end{array}$ & $\begin{array}{l}32.654 \\
(0.1494)\end{array}$ \\
\hline H.S. Dropout & $\begin{array}{c}0.561 \\
(0.0006)\end{array}$ & $\begin{array}{c}0.678 \\
(0.0027)\end{array}$ & $\begin{array}{c}0.556 \\
(0.0080)\end{array}$ & $\begin{array}{c}0.436 \\
(0.0007)\end{array}$ & $\begin{array}{c}0.502 \\
(0.0029)\end{array}$ & $\begin{array}{c}0.474 \\
(0.0066)\end{array}$ \\
\hline H.S. Degree & $\begin{array}{c}0.248 \\
(0.0006)\end{array}$ & $\begin{array}{c}0.148 \\
(0.0021)\end{array}$ & $\begin{array}{c}0.157 \\
(0.0059)\end{array}$ & $\begin{array}{c}0.307 \\
(0.0006)\end{array}$ & $\begin{array}{c}0.212 \\
(0.0024)\end{array}$ & $\begin{array}{c}0.178 \\
(0.0050)\end{array}$ \\
\hline Some College & $\begin{array}{c}0.098 \\
(0.0004)\end{array}$ & $\begin{array}{c}0.081 \\
(0.0016)\end{array}$ & $\begin{array}{c}0.127 \\
(0.0054)\end{array}$ & $\begin{array}{c}0.135 \\
(0.0005)\end{array}$ & $\begin{array}{c}0.126 \\
(0.0019)\end{array}$ & $\begin{array}{c}0.124 \\
(0.0043)\end{array}$ \\
\hline College Graduate & $\begin{array}{c}0.091 \\
(0.0004)\end{array}$ & $\begin{array}{c}0.093 \\
(0.0017)\end{array}$ & $\begin{array}{c}0.160 \\
(0.0059)\end{array}$ & $\begin{array}{c}0.122 \\
(0.0004)\end{array}$ & $\begin{array}{c}0.160 \\
(0.0021)\end{array}$ & $\begin{array}{c}0.224 \\
(0.0055)\end{array}$ \\
\hline Black & $\begin{array}{c}0.099 \\
(0.0004)\end{array}$ & $\begin{array}{l}0.017 \\
(0.0008)\end{array}$ & $\begin{array}{c}0.034 \\
(0.0029)\end{array}$ & $\begin{array}{l}0.100 \\
(0.0004)\end{array}$ & $\begin{array}{l}0.036 \\
(0.0011)\end{array}$ & $\begin{array}{c}0.067 \\
(0.0033)\end{array}$ \\
\hline Asian $^{a}$ & - & - & - & - & - & - \\
\hline Other Race ${ }^{a}$ & $\begin{array}{l}0.007 \\
(0.0001)\end{array}$ & $\begin{array}{l}0.050 \\
(0.0013)\end{array}$ & $\begin{array}{c}0.074 \\
(0.0029)\end{array}$ & $\begin{array}{c}0.009 \\
(0.0001)\end{array}$ & $\begin{array}{c}0.081 \\
(0.0016)\end{array}$ & $\begin{array}{c}0.158 \\
(0.0048)\end{array}$ \\
\hline Hispanic $^{b}$ & $\begin{array}{c}0.015 \\
(0.0002)\end{array}$ & $\begin{array}{c}0.078 \\
(0.0015)\end{array}$ & $\begin{array}{c}0.163 \\
(0.0060)\end{array}$ & $\begin{array}{c}0.032 \\
(0.0002)\end{array}$ & $\begin{array}{c}0.218 \\
(0.0024)\end{array}$ & $\begin{array}{c}0.342 \\
(0.0062)\end{array}$ \\
\hline Married & $\begin{array}{c}0.715 \\
(0.0006)\end{array}$ & $\begin{array}{c}0.780 \\
(0.0024)\end{array}$ & $\begin{array}{c}0.596 \\
(0.0079)\end{array}$ & $\begin{array}{c}0.678 \\
(0.0006)\end{array}$ & $\begin{array}{l}0.744 \\
(0.0026)\end{array}$ & $\begin{array}{c}0.640 \\
(0.0063)\end{array}$ \\
\hline Metropolitan Area & $\begin{array}{c}0.569 \\
(0.0007)\end{array}$ & $\begin{array}{c}0.808 \\
(0.0023)\end{array}$ & $\begin{array}{c}0.787 \\
(0.0066)\end{array}$ & $\begin{array}{c}0.622 \\
(0.0006)\end{array}$ & $\begin{array}{c}0.824 \\
(0.0022)\end{array}$ & $\begin{array}{c}0.853 \\
(0.0046)\end{array}$ \\
\hline Log Hourly Wagec (1990\$’s) & $\begin{array}{c}2.218 \\
(0.0011)\end{array}$ & $\begin{array}{c}2.271 \\
(0.0042)\end{array}$ & $\begin{array}{c}2.017 \\
(0.0136)\end{array}$ & $\begin{array}{c}2.447 \\
(0.0011)\end{array}$ & $\begin{array}{c}2.483 \\
(0.0046)\end{array}$ & $\begin{array}{c}2.293 \\
(0.0111)\end{array}$ \\
\hline Fraction of the Population & - & $\begin{array}{c}0.058 \\
(0.0003)\end{array}$ & $\begin{array}{c}0.007 \\
(0.0001)\end{array}$ & - & $\begin{array}{c}0.050 \\
(0.0003)\end{array}$ & $\begin{array}{c}0.010 \\
(0.0001)\end{array}$ \\
\hline Sample Size ${ }^{e}$ & 484,963 & 29,982 & 3,816 & 560,088 & 29,209 & 5,806 \\
\hline
\end{tabular}


Appendix Table Al. Continued

\begin{tabular}{|c|c|c|c|c|c|c|}
\hline \multirow[b]{2}{*}{ Variable Name } & \multicolumn{3}{|c|}{1980} & \multicolumn{3}{|c|}{$1990^{\mathrm{d}}$} \\
\hline & Native-Born & Immigrants & $\begin{array}{c}\text { Recent } \\
\text { Immigrants }\end{array}$ & Native-Born & Immigrants & $\begin{array}{c}\text { Recent } \\
\text { Immigrants }\end{array}$ \\
\hline Age & $\begin{array}{l}36.268 \\
(0.0151)\end{array}$ & $\begin{array}{l}37.030 \\
(0.0536)\end{array}$ & $\begin{array}{l}29.977 \\
(0.0836)\end{array}$ & $\begin{array}{l}37.100 \\
(0.0143)\end{array}$ & $\begin{array}{l}36.405 \\
(0.0420)\end{array}$ & $\begin{array}{l}30.196 \\
(0.0728)\end{array}$ \\
\hline H.S. Dropout & $\begin{array}{c}0.304 \\
(0.0005)\end{array}$ & $\begin{array}{c}0.400 \\
(0.0019)\end{array}$ & $\begin{array}{c}0.419 \\
(0.0038)\end{array}$ & $\begin{array}{c}0.224 \\
(0.0004)\end{array}$ & $\begin{array}{c}0.407 \\
(0.0016)\end{array}$ & $\begin{array}{c}0.444 \\
(0.0034)\end{array}$ \\
\hline H.S. Degree & $\begin{array}{l}0.345 \\
(0.0005)\end{array}$ & $\begin{array}{c}0.229 \\
(0.0017)\end{array}$ & $\begin{array}{c}0.199 \\
(0.0031)\end{array}$ & $\begin{array}{c}0.290 \\
(0.0005)\end{array}$ & $\begin{array}{c}0.174 \\
(0.0013)\end{array}$ & $\begin{array}{c}0.170 \\
(0.0025)\end{array}$ \\
\hline Some College & $\begin{array}{l}0.179 \\
(0.0004)\end{array}$ & $\begin{array}{c}0.167 \\
(0.0015)\end{array}$ & $\begin{array}{c}0.178 \\
(0.0030)\end{array}$ & $\begin{array}{c}0.276 \\
(0.0005)\end{array}$ & $\begin{array}{l}0.200 \\
(0.0013)\end{array}$ & $\begin{array}{c}0.172 \\
(0.0025)\end{array}$ \\
\hline College Graduate & $\begin{array}{l}0.172 \\
(0.0004)\end{array}$ & $\begin{array}{c}0.204 \\
(0.0016)\end{array}$ & $\begin{array}{l}0.205 \\
(0.0031)\end{array}$ & $\begin{array}{l}0.210 \\
(0.0004)\end{array}$ & $\begin{array}{c}0.219 \\
(0.0014)\end{array}$ & $\begin{array}{c}0.214 \\
(0.0028)\end{array}$ \\
\hline Black & $\begin{array}{l}0.108 \\
(0.0003)\end{array}$ & $\begin{array}{l}0.065 \\
(0.0010)\end{array}$ & $\begin{array}{c}0.071 \\
(0.0020)\end{array}$ & $\begin{array}{l}0.115 \\
(0.0003)\end{array}$ & $\begin{array}{c}0.077 \\
(0.0009)\end{array}$ & $\begin{array}{c}0.075 \\
(0.0018)\end{array}$ \\
\hline Asian & $\begin{array}{l}0.006 \\
(0.00001)\end{array}$ & $\begin{array}{l}0.155 \\
(0.0014)\end{array}$ & $\begin{array}{c}0.260 \\
(0.0034)\end{array}$ & $\begin{array}{l}0.006 \\
(0.0001)\end{array}$ & $\begin{array}{c}0.231 \\
(0.0014)\end{array}$ & $\begin{array}{c}0.272 \\
(0.0030)\end{array}$ \\
\hline Other Race & $\begin{array}{c}0.020 \\
(0.0005)\end{array}$ & $\begin{array}{c}0.169 \\
(0.0015)\end{array}$ & $\begin{array}{c}0.228 \\
(0.0032)\end{array}$ & $\begin{array}{c}0.028 \\
(0.0002)\end{array}$ & $\begin{array}{c}0.226 \\
(0.0014)\end{array}$ & $\begin{array}{c}0.257 \\
(0.0030)\end{array}$ \\
\hline Hispanic & $\begin{array}{c}0.036 \\
(0.0002)\end{array}$ & $\begin{array}{c}0.351 \\
(0.0019)\end{array}$ & $\begin{array}{c}0.368 \\
(0.0037)\end{array}$ & $\begin{array}{c}0.045 \\
(0.0002)\end{array}$ & $\begin{array}{c}0.445 \\
(0.0017)\end{array}$ & $\begin{array}{c}0.478 \\
(0.0034)\end{array}$ \\
\hline Married & $\begin{array}{l}0.606 \\
(0.0005)\end{array}$ & $\begin{array}{c}0.658 \\
(0.0019)\end{array}$ & $\begin{array}{c}0.517 \\
(0.0039)\end{array}$ & $\begin{array}{c}0.569 \\
(0.0005)\end{array}$ & $\begin{array}{c}0.613 \\
(0.0016)\end{array}$ & $\begin{array}{c}0.474 \\
(0.0034)\end{array}$ \\
\hline Metropolitan Area & $\begin{array}{l}0.800 \\
(0.0004)\end{array}$ & $\begin{array}{c}0.945 \\
(0.0009)\end{array}$ & $\begin{array}{c}0.945 \\
(0.0018)\end{array}$ & $\begin{array}{c}0.822 \\
(0.0004)\end{array}$ & $\begin{array}{c}0.957 \\
(0.0007)\end{array}$ & $\begin{array}{c}0.956 \\
(0.0014)\end{array}$ \\
\hline Log Hourly Wagec (1990 \$'s) & $\begin{array}{c}2.386 \\
(0.0008)\end{array}$ & $\begin{array}{c}2.364 \\
(0.0032)\end{array}$ & $\begin{array}{c}2.127 \\
(0.0068)\end{array}$ & $\begin{array}{c}2.337 \\
(0.0009)\end{array}$ & $\begin{array}{c}2.242 \\
(0.0028)\end{array}$ & $\begin{array}{c}1.995 \\
(0.0059)\end{array}$ \\
\hline Fraction of the Population & - & $\begin{array}{c}0.066 \\
(0.0003)\end{array}$ & $\begin{array}{c}0.017 \\
(0.0001)\end{array}$ & - & $\begin{array}{c}0.091 \\
(0.0003)\end{array}$ & $\begin{array}{c}0.022 \\
(0.0001)\end{array}$ \\
\hline Sample Size ${ }^{e}$ & 900,991 & 63,221 & 16,760 & 885,629 & 89,174 & 21,850 \\
\hline
\end{tabular}

Notes: Data are from the PUMS of the 1960-90 U.S. Censuses. Ages 16-65 are included.

${ }^{a}$ Asian and Other Race are combined in 1960 and 1970.

bIn 1960 "Hispanic" refers to those with "Spanish" surnames; in the other years it refers to those who self-identify as Hispanic.

'Only those with valid log hourly wages are included in this calculation.

${ }^{d} 1990$ data are weighted using PUMS sampling weights.

'The sample size is for the entire sample, not just for those with valid wages. 
Appendix Table A2

Descriptive Statistics for Women : Native-Born, Immigrants, and Recent Immigrants, by Year (Standard Errors in Parentheses)

\begin{tabular}{|c|c|c|c|c|c|c|}
\hline \multirow[b]{2}{*}{ Variable Name } & \multicolumn{3}{|c|}{1960} & \multicolumn{3}{|c|}{1970} \\
\hline & Native-Born & Immigrants & $\begin{array}{c}\text { Recent } \\
\text { Immigrants }\end{array}$ & Native-Born & Immigrants & $\begin{array}{c}\text { Recent } \\
\text { Immigrants }\end{array}$ \\
\hline Age & $\begin{array}{l}38.140 \\
(0.0193)\end{array}$ & $\begin{array}{l}46.535 \\
(0.0755)\end{array}$ & $\begin{array}{l}31.972 \\
(0.1666)\end{array}$ & $\begin{array}{l}37.629 \\
(0.0189)\end{array}$ & $\begin{array}{l}41.411 \\
(0.0764)\end{array}$ & $\begin{array}{l}32.166 \\
(0.1390)\end{array}$ \\
\hline H.S. Dropout & $\begin{array}{c}0.523 \\
(0.0007)\end{array}$ & $\begin{array}{c}0.680 \\
(0.0026)\end{array}$ & $\begin{array}{c}0.575 \\
(0.0075)\end{array}$ & $\begin{array}{c}0.414 \\
(0.0006)\end{array}$ & $\begin{array}{l}0.516 \\
(0.0027)\end{array}$ & $\begin{array}{c}0.524 \\
(0.0060)\end{array}$ \\
\hline H.S. Degree & $\begin{array}{c}0.321 \\
(0.0007)\end{array}$ & $\begin{array}{c}0.207 \\
(0.0023)\end{array}$ & $\begin{array}{c}0.253 \\
(0.0066)\end{array}$ & $\begin{array}{c}0.383 \\
(0.0006)\end{array}$ & $\begin{array}{l}0.296 \\
(0.0024)\end{array}$ & $\begin{array}{c}0.252 \\
(0.0052)\end{array}$ \\
\hline Some College & $\begin{array}{c}0.099 \\
(0.0004)\end{array}$ & $\begin{array}{c}0.074 \\
(0.0015)\end{array}$ & $\begin{array}{c}0.115 \\
(0.0048)\end{array}$ & $\begin{array}{c}0.125 \\
(0.0004)\end{array}$ & $\begin{array}{c}0.112 \\
(0.0017)\end{array}$ & $\begin{array}{c}0.111 \\
(0.0038)\end{array}$ \\
\hline College Graduate & $\begin{array}{c}0.057 \\
(0.0003)\end{array}$ & $\begin{array}{c}0.039 \\
(0.0011)\end{array}$ & $\begin{array}{c}0.057 \\
(0.0035)\end{array}$ & $\begin{array}{c}0.078 \\
(0.0003)\end{array}$ & $\begin{array}{c}0.077 \\
(0.0014)\end{array}$ & $\begin{array}{c}0.112 \\
(0.0038)\end{array}$ \\
\hline Black & $\begin{array}{c}0.107 \\
(0.0004)\end{array}$ & $\begin{array}{l}0.015 \\
(0.0007)\end{array}$ & $\begin{array}{c}0.023 \\
(0.0023)\end{array}$ & $\begin{array}{c}0.111 \\
(0.0004)\end{array}$ & $\begin{array}{c}0.036 \\
(0.0010)\end{array}$ & $\begin{array}{c}0.076 \\
(0.0032)\end{array}$ \\
\hline Asian & - & - & - & - & - & - \\
\hline Other Race ${ }^{a}$ & $\begin{array}{c}0.007 \\
(0.0001)\end{array}$ & $\begin{array}{c}0.033 \\
(0.0010)\end{array}$ & $\begin{array}{c}0.091 \\
(0.0043)\end{array}$ & $\begin{array}{c}0.009 \\
(0.0001)\end{array}$ & $\begin{array}{c}0.075 \\
(0.0014)\end{array}$ & $\begin{array}{c}0.156 \\
(0.0044)\end{array}$ \\
\hline Hispanic $^{b}$ & $\begin{array}{c}0.014 \\
(0.0002)\end{array}$ & $\begin{array}{c}0.060 \\
(0.0013)\end{array}$ & $\begin{array}{c}0.073 \\
(0.0039)\end{array}$ & $\begin{array}{c}0.032 \\
(0.0002)\end{array}$ & $\begin{array}{l}0.205 \\
(0.0021)\end{array}$ & $\begin{array}{c}0.347 \\
(0.0057)\end{array}$ \\
\hline Married & $\begin{array}{c}0.714 \\
(0.0006)\end{array}$ & $\begin{array}{c}0.735 \\
(0.0025)\end{array}$ & $\begin{array}{c}0.713 \\
(0.0068)\end{array}$ & $\begin{array}{l}0.666 \\
(0.0006)\end{array}$ & $\begin{array}{c}0.718 \\
(0.0024)\end{array}$ & $\begin{array}{c}0.687 \\
(0.0056)\end{array}$ \\
\hline Metropolitan Area & $\begin{array}{l}0.580 \\
(0.0007)\end{array}$ & $\begin{array}{c}0.812 \\
(0.0022)\end{array}$ & $\begin{array}{c}0.802 \\
(0.0060)\end{array}$ & $\begin{array}{c}0.629 \\
(0.0006)\end{array}$ & $\begin{array}{c}0.817 \\
(0.0021)\end{array}$ & $\begin{array}{c}0.845 \\
(0.0044)\end{array}$ \\
\hline Log Hourly Wage $(1990 \$)^{c}$ & $\begin{array}{l}1.830 \\
(0.0017)\end{array}$ & $\begin{array}{l}1.853 \\
(0.0063)\end{array}$ & $\begin{array}{c}1.690 \\
(0.0164)\end{array}$ & $\begin{array}{l}2.048 \\
(0.0013)\end{array}$ & $\begin{array}{c}2.081 \\
(0.0057)\end{array}$ & $\begin{array}{c}1.974 \\
(0.0131)\end{array}$ \\
\hline Fraction of the Population & - & $\begin{array}{c}0.060 \\
(0.0003)\end{array}$ & $\begin{array}{c}0.008 \\
(0.0001)\end{array}$ & - & $\begin{array}{c}0.055 \\
(0.0003)\end{array}$ & $\begin{array}{c}0.011 \\
(0.0001)\end{array}$ \\
\hline \multirow[t]{2}{*}{ Sample Size ${ }^{e}$} & 507,058 & 32,294 & 4,399 & 593,616 & 34,858 & 6,926 \\
\hline & \multicolumn{3}{|c|}{1980} & \multicolumn{3}{|c|}{$1990^{\mathrm{d}}$} \\
\hline Variable Name & Native-Born & Immigrants & $\begin{array}{c}\text { Recent } \\
\text { Immigrants }\end{array}$ & Native-Born & Immigrants & $\begin{array}{c}\text { Recent } \\
\text { Immigrants }\end{array}$ \\
\hline Age & $\begin{array}{l}36.903 \\
(0.0150)\end{array}$ & $\begin{array}{l}38.600 \\
(0.0512)\end{array}$ & $\begin{array}{l}31.328 \\
(0.0939)\end{array}$ & $\begin{array}{l}37.625 \\
(0.0142)\end{array}$ & $\begin{array}{l}38.341 \\
(0.0431)\end{array}$ & $\begin{array}{l}31.416 \\
(0.0789)\end{array}$ \\
\hline H.S. Dropout & $\begin{array}{c}0.292 \\
(0.0005)\end{array}$ & $\begin{array}{l}0.411 \\
(0.0019)\end{array}$ & $\begin{array}{c}0.459 \\
(0.0040)\end{array}$ & $\begin{array}{l}0.206 \\
(0.0004)\end{array}$ & $\begin{array}{c}0.392 \\
(0.0016)\end{array}$ & $\begin{array}{c}0.421 \\
(0.0035)\end{array}$ \\
\hline H.S. Degree & $\begin{array}{l}0.410 \\
(0.0005)\end{array}$ & $\begin{array}{c}0.301 \\
(0.0017)\end{array}$ & $\begin{array}{c}0.239 \\
(0.0034)\end{array}$ & $\begin{array}{c}0.322 \\
(0.0005)\end{array}$ & $\begin{array}{c}0.223 \\
(0.0014)\end{array}$ & $\begin{array}{c}0.210 \\
(0.0029)\end{array}$ \\
\hline Some College & $\begin{array}{c}0.178 \\
(0.0004)\end{array}$ & $\begin{array}{c}0.162 \\
(0.0014)\end{array}$ & $\begin{array}{c}0.154 \\
(0.0029)\end{array}$ & $\begin{array}{l}0.296 \\
(0.0005)\end{array}$ & $\begin{array}{l}0.214 \\
(0.0014)\end{array}$ & $\begin{array}{c}0.183 \\
(0.0027)\end{array}$ \\
\hline College Graduate & $\begin{array}{c}0.119 \\
(0.0003)\end{array}$ & $\begin{array}{c}0.127 \\
(0.0013)\end{array}$ & $\begin{array}{c}0.147 \\
(0.0028)\end{array}$ & $\begin{array}{c}0.175 \\
(0.0004)\end{array}$ & $\begin{array}{c}0.172 \\
(0.0013)\end{array}$ & $\begin{array}{c}0.186 \\
(0.0027)\end{array}$ \\
\hline Black & $\begin{array}{c}0.122 \\
(0.0003)\end{array}$ & $\begin{array}{l}0.065 \\
(0.0009)\end{array}$ & $\begin{array}{l}0.073 \\
(0.0021)\end{array}$ & $\begin{array}{c}0.128 \\
(0.0003)\end{array}$ & $\begin{array}{c}0.080 \\
(0.0009)\end{array}$ & $\begin{array}{c}0.080 \\
(0.0019)\end{array}$ \\
\hline Asian & $\begin{array}{c}0.006 \\
(0.0001)\end{array}$ & $\begin{array}{l}0.166 \\
(0.0014)\end{array}$ & $\begin{array}{c}0.311 \\
(0.0037)\end{array}$ & $\begin{array}{l}0.006 \\
(0.0001)\end{array}$ & $\begin{array}{l}0.253 \\
(0.0014)\end{array}$ & $\begin{array}{c}0.320 \\
(0.0033)\end{array}$ \\
\hline Other Race & $\begin{array}{c}0.020 \\
(0.0001)\end{array}$ & $\begin{array}{c}0.138 \\
(0.0013)\end{array}$ & $\begin{array}{c}0.191 \\
(0.0031)\end{array}$ & $\begin{array}{c}0.027 \\
(0.0002)\end{array}$ & $\begin{array}{c}0.183 \\
(0.0013)\end{array}$ & $\begin{array}{c}0.205 \\
(0.0028)\end{array}$ \\
\hline Hispanic & $\begin{array}{c}0.035 \\
(0.0002)\end{array}$ & $\begin{array}{c}0.316 \\
(0.0018)\end{array}$ & $\begin{array}{c}0.336 \\
(0.0038)\end{array}$ & $\begin{array}{c}0.044 \\
(0.0002)\end{array}$ & $\begin{array}{c}0.395 \\
(0.0016)\end{array}$ & $\begin{array}{c}0.423 \\
(0.0035)\end{array}$ \\
\hline Married & $\begin{array}{c}0.601 \\
(0.0005)\end{array}$ & $\begin{array}{c}0.681 \\
(0.0018)\end{array}$ & $\begin{array}{c}0.630 \\
(0.0039)\end{array}$ & $\begin{array}{l}0.569 \\
(0.0005)\end{array}$ & $\begin{array}{c}0.642 \\
(0.0016)\end{array}$ & $\begin{array}{c}0.580 \\
(0.0035)\end{array}$ \\
\hline Metropolitan Area & $\begin{array}{l}0.803 \\
(0.0004)\end{array}$ & $\begin{array}{c}0.940 \\
(0.0009)\end{array}$ & $\begin{array}{c}0.952 \\
(0.0017)\end{array}$ & $\begin{array}{l}0.825 \\
(0.0004)\end{array}$ & $\begin{array}{c}0.958 \\
(0.0007)\end{array}$ & $\begin{array}{c}0.962 \\
(0.0013)\end{array}$ \\
\hline Log Hourly Wage $(1990 \$ s)^{c}$ & $\begin{array}{l}1.991 \\
(0.0008)\end{array}$ & $\begin{array}{l}2.026 \\
(0.0033)\end{array}$ & $\begin{array}{l}1.871 \\
(0.0076)\end{array}$ & $\begin{array}{l}2.042 \\
(0.0008)\end{array}$ & $\begin{array}{l}2.047 \\
(0.0029)\end{array}$ & $\begin{array}{l}1.849 \\
(0.0070)\end{array}$ \\
\hline Fraction of the Population & - & $\begin{array}{c}0.069 \\
(0.0003)\end{array}$ & $\begin{array}{l}0.016 \\
(0.0001)\end{array}$ & - & $\begin{array}{c}0.089 \\
(0.0003)\end{array}$ & $\begin{array}{c}0.020 \\
(0.0001)\end{array}$ \\
\hline Sample Size ${ }^{e}$ & 939,397 & 69,125 & 15,643 & 921,739 & 90,347 & 20,225 \\
\hline
\end{tabular}

Notes: see notes to Table A1. 


\section{REFERENCES}

Baker, Michael, and Dwayne Benjamin. 1997. "The Role of the Family in Immigrants' Labor Market Activity: An Evaluation of Alternative Explanations." American Economic Review, Vol. 87, No. 4 (September), pp. 705-27.

Beach, Charles, and Christopher Worswick. 1993. "Is There a Double-Negative Effect on the Earnings of Immigrant Women?" Canadian Public Policy, Vol. 19 , No. 1, pp. 36-53.

Blau, Francine, and Andrea Beller. 1992. "Black White Earnings over the 1970s and 1980s: Gender Differences in Trends." Review of Economics and Statistics, Vol. 74, No. 2, pp. 276-86.

Blinder, Alan S. 1973. "Wage Discrimination: Reduced Form and Structural Estimates." Journal of Human Resources, Vol. 8, No. 4, pp. 436-55.

Borjas, George J. 1987. "Self-Selection and the Earnings of Immigrants." American Economic Review, Vol. 77, No. 4, pp. 531-53.

1990. Friends or Strangers: The Impact of Immigrants on the U.S. Economy. New York: Basic Books. 1991. "National Origin and the Skills of Immigrants in the Postwar Period." NBER Working Paper 3675 .

1994. "The Economics of Immigration." Journal of Economic Literature, Vol. 32, No. 4, pp. 16671717.

1995. "Assimilation and Changes in Cohort Quality Revisited: What Happened to Immigrant Earnings in the 1980s?" Journal of Labor Economics, Vol. 13, No. 2, pp. 201-45.

Card, David, and Thomas Lemieux. 1996. "Wage Dispersion, Returns to Skill, and Black-White Wage Differentials." Journal of Econometrics, Vol. 74, No. 2, pp. 319-61.

Chay, Kenneth Y., and David S. Lee. 1996. "Changes in Relative Wages in the 1980s: Returns to Observed and Unobserved Skills and Black-Wage Wage Differentials." Working Paper 372, Industrial Relations Section, Princeton University.

Cohen, Yinon, Tzippi Zach, and Barry Chiswick. 1997. "The Educational Attainment of Immigrants: Changes over Time." Quarterly Review of Economics and Finance, Vol. 37, No. 0 (Special Issue), pp. 22943.

Deschênes, O. 2001. "Unobserved Ability, Comparative Advantage, and the Rising Return to Education in the United States, 1979-2000: Estimating the Effect of Family Background on the Return to Schooling." Unpublished manuscript, University of California, Santa Barbara.

DiNardo, John, Nicole Fortin, and Thomas Lemieux. 1996. "Labor Market Institutions and the Distribution of Wages, 1973-1992: A Semi-Parametric Approach." Econometrica, Vol. 64, No. 5 (September), pp. 1001-44.

DiNardo, John, and Jorn-Steffen Pischke. 1997. "The Returns to Computer Use Revisited: Have Pencils Changed the Wage Structure Too?" Quarterly Journal of Economics, Vol. 112, No. 1 (February), pp. 291303.
Duleep, Harriet Orcutt, and Seth Sanders. 1993. "The Decision to Work by Married Immigrant Women." Industrial and Labor Relations Review, Vol. 46, No. 4 (July), pp. 677-90.

Funkhouser, Edward, and Stephen J. Trejo. 1995. "The Labor Market Skills of Recent Male Immigrants: Evidence from the Current Population Survey." Industrial and Labor Relations Review, Vol. 48, No. 4 (July), pp. 792-811.

Jasso, Guillermina, Mark R. Rosenzweig, and James P. Smith. 2000. "The Changing Skill of New Immigrants to the United States: Recent Trends and Their Determinants." In George Borjas, ed., Issues in the Economics of Immigration. Chicago: University of Chicago Press and NBER.

Katz, Lawrence, and Kevin Murphy. 1992. “Changes in Relative Wages, 1963-1987: Supply and Demand Factors." Quarterly Journal of Economics, Vol. 107, No. 1 (February), pp. 35-78.

LaLonde, Robert J., and Robert H. Topel. 1992. "The Assimilation of Immigrants in the U.S. Labor Market." In George J. Borjas and Richard B. Freeman, eds., Immigration and the Work Force: Economic Consequences for the United States and Source Areas. A National Bureau of Economic Research project report. Chicago: University of Chicago Press, pp. 67-92.

Lubotsky, Darren. 2000. "Chutes or Ladders? A Longitudinal Analysis of Immigrant Earnings." Industrial Relations Section Working Paper 445, Princeton University.

2001. "The Effect of Changes in the U.S. Wage Structure on Recent Immigrants' Earnings." Unpublished manuscript, Woodrow Wilson School of Public and International Affairs, Princeton, N.J.

Oaxaca, Robert. 1973. "Male-Female Wage Differentials in Urban Labor Markets." International Economic Review, Vol. 14, No. 3 (October), pp. 693-709.

Parzen, Emanuel. 1962. "On Estimation of a Probability Density Function and Mode." Annals of Mathematical Statistics, Vol. 33, pp. 1065-76.

Reimers, David M. 1981. "Post World War II Immigration to the United States: America's Latest Newcomers." Annals of the American Academy of Political and Social Science, Vol. 454, pp. 1-12.

Rosenblatt, Murray. 1956. "Remarks on Some NonParametric Estimates of a Density Function." $A n$ nals of Mathematical Statistics, Vol. 27, pp. 832-37.

Schoeni, Robert F. 1998. "Labor Market Assimilation of Immigrant Women." Industrial and Relations Review, Vol. 51, No. 3 (April), pp. 483-504.

Sheather, S., and M. Jones. 1991. "A Reliable DataBased Bandwidth Selection Method for Kernel Density Estimation." Journal of the Royal Statistical Society, Series B, Vol. 53, pp. 683-90.

Silverman, Bertram W. 1986. Density Estimation for Statistics and Data Analysis. London: Chapman \& Hall.

Simon, Julian, and Ather H. Akbari 1996. "Determinants of Welfare Payment Use by Immigrants and Natives in the United States and Canada." In Harriet Orcutt Duleep and Phanindra V. Wunnava, eds., 
Immigrants and Immigration Policy: Individual Skills, Family Ties, and Group Identities. Greenwich, Conn.: JAI Press, pp. 79-100.

Yuengert, Andrew M. 1994. "Immigrant Earnings,
Relative to What? The Importance of Earnings Function Specification and Comparison Points." Journal of Applied Econometrics, Vol. 9, No. 1, pp. 7190. 
http://www.jstor.org

\title{
LINKED CITATIONS
}

- Page 1 of 4 -

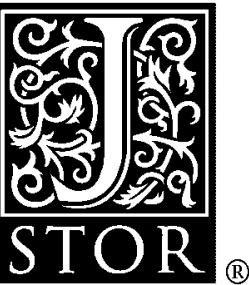

You have printed the following article:

The Immigrant and Native-Born Wage Distributions: Evidence from United States Censuses

Kristin F. Butcher; John Dinardo

Industrial and Labor Relations Review, Vol. 56, No. 1. (Oct., 2002), pp. 97-121.

Stable URL:

http://links.jstor.org/sici?sici=0019-7939\%28200210\%2956\%3A1\%3C97\%3ATIANWD\%3E2.0.CO\%3B2-H

This article references the following linked citations. If you are trying to access articles from an off-campus location, you may be required to first logon via your library web site to access JSTOR. Please visit your library's website or contact a librarian to learn about options for remote access to JSTOR.

\section{[Footnotes]}

\author{
${ }^{1}$ The Decision to Work by Married Immigrant Women \\ Harriet Orcutt Duleep; Seth Sanders \\ Industrial and Labor Relations Review, Vol. 46, No. 4. (Jul., 1993), pp. 677-690. \\ Stable URL: \\ http://links.jstor.org/sici?sici=0019-7939\%28199307\%2946\%3A4\%3C677\%3ATDTWBM\%3E2.0.CO\%3B2-4
}

\section{${ }^{1}$ The Role of the Family in Immigrants' Labor-Market Activity: An Evaluation of Alternative Explanations}

Michael Baker; Dwayne Benjamin

The American Economic Review, Vol. 87, No. 4. (Sep., 1997), pp. 705-727.

Stable URL:

http://links.jstor.org/sici?sici=0002-8282\%28199709\%2987\%3A4\%3C705\%3ATROTFI\%3E2.0.CO\%3B2-U

\author{
${ }^{9}$ Black-White Earnings Over the 1970s and 1980s: Gender Differences in Trends \\ Francine D. Blau; Andrea H. Beller \\ The Review of Economics and Statistics, Vol. 74, No. 2. (May, 1992), pp. 276-286. \\ Stable URL: \\ http://links.jstor.org/sici?sici=0034-6535\%28199205\%2974\%3A2\%3C276\%3ABEOT1A\%3E2.0.CO\%3B2-1
}

\section{References}

NOTE: The reference numbering from the original has been maintained in this citation list. 
http://www.jstor.org

\title{
LINKED CITATIONS
}

- Page 2 of 4 -

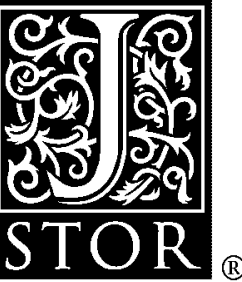

The Role of the Family in Immigrants' Labor-Market Activity: An Evaluation of Alternative Explanations

Michael Baker; Dwayne Benjamin

The American Economic Review, Vol. 87, No. 4. (Sep., 1997), pp. 705-727.

Stable URL:

http://links.jstor.org/sici?sici=0002-8282\%28199709\%2987\%3A4\%3C705\%3ATROTFI\%3E2.0.CO\%3B2-U

Black-White Earnings Over the 1970s and 1980s: Gender Differences in Trends

Francine D. Blau; Andrea H. Beller

The Review of Economics and Statistics, Vol. 74, No. 2. (May, 1992), pp. 276-286.

Stable URL:

http://links.jstor.org/sici?sici=0034-6535\%28199205\%2974\%3A2\%3C276\%3ABEOT1A\%3E2.0.CO\%3B2-1

\section{Wage Discrimination: Reduced Form and Structural Estimates}

Alan S. Blinder

The Journal of Human Resources, Vol. 8, No. 4. (Autumn, 1973), pp. 436-455.

Stable URL:

http://links.jstor.org/sici?sici=0022-166X\%28197323\%298\%3A4\%3C436\%3AWDRFAS\%3E2.0.CO\%3B2-U

\section{Self-Selection and the Earnings of Immigrants}

George J. Borjas

The American Economic Review, Vol. 77, No. 4. (Sep., 1987), pp. 531-553.

Stable URL:

http://links.jstor.org/sici?sici=0002-8282\%28198709\%2977\%3A4\%3C531\%3ASATEOI\%3E2.0.CO\%3B2-3

\section{The Economics of Immigration}

George J. Borjas

Journal of Economic Literature, Vol. 32, No. 4. (Dec., 1994), pp. 1667-1717.

Stable URL:

http://links.jstor.org/sici?sici=0022-0515\%28199412\%2932\%3A4\%3C1667\%3ATEOI\%3E2.0.CO\%3B2-W

\author{
Assimilation and Changes in Cohort Quality Revisited: What Happened to Immigrant \\ Earnings in the 1980s? \\ George J. Borjas \\ Journal of Labor Economics, Vol. 13, No. 2. (Apr., 1995), pp. 201-245. \\ Stable URL: \\ http://links.jstor.org/sici?sici=0734-306X\%28199504\%2913\%3A2\%3C201\%3AAACICQ\%3E2.0.CO\%3B2-W
}

NOTE: The reference numbering from the original has been maintained in this citation list. 
http://www.jstor.org

\section{LINKED CITATIONS}

- Page 3 of 4 -

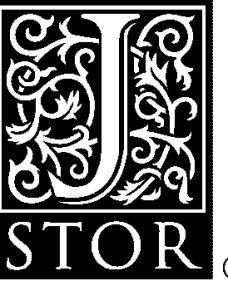

Labor Market Institutions and the Distribution of Wages, 1973-1992: A Semiparametric Approach

John DiNardo; Nicole M. Fortin; Thomas Lemieux

Econometrica, Vol. 64, No. 5. (Sep., 1996), pp. 1001-1044.

Stable URL:

http://links.jstor.org/sici?sici=0012-9682\%28199609\%2964\%3A5\%3C1001\%3ALMIATD\%3E2.0.CO\%3B2-K

The Returns to Computer Use Revisited: Have Pencils Changed the Wage Structure Too?

John E. DiNardo; Jorn-Steffen Pischke

The Quarterly Journal of Economics, Vol. 112, No. 1. (Feb., 1997), pp. 291-303.

Stable URL:

http://links.jstor.org/sici?sici=0033-5533\%28199702\%29112\%3A1\%3C291\%3ATRTCUR\%3E2.0.CO\%3B2-N

\section{The Decision to Work by Married Immigrant Women}

Harriet Orcutt Duleep; Seth Sanders

Industrial and Labor Relations Review, Vol. 46, No. 4. (Jul., 1993), pp. 677-690.

Stable URL:

http://links.jstor.org/sici?sici=0019-7939\%28199307\%2946\%3A4\%3C677\%3ATDTWBM\%3E2.0.CO\%3B2-4

The Labor Market Skills of Recent Male Immigrants: Evidence from the Current Population Survey

Edward Funkhouser; Stephen J. Trejo

Industrial and Labor Relations Review, Vol. 48, No. 4. (Jul., 1995), pp. 792-811.

Stable URL:

http://links.jstor.org/sici?sici=0019-7939\%28199507\%2948\%3A4\%3C792\%3ATLMSOR\%3E2.0.CO\%3B2-Z

Changes in Relative Wages, 1963-1987: Supply and Demand Factors

Lawrence F. Katz; Kevin M. Murphy

The Quarterly Journal of Economics, Vol. 107, No. 1. (Feb., 1992), pp. 35-78.

Stable URL:

http://links.jstor.org/sici?sici=0033-5533\%28199202\%29107\%3A1\%3C35\%3ACIRW1S\%3E2.0.CO\%3B2-O

\section{Male-Female Wage Differentials in Urban Labor Markets}

Ronald Oaxaca

International Economic Review, Vol. 14, No. 3. (Oct., 1973), pp. 693-709.

Stable URL:

http://links.jstor.org/sici?sici=0020-6598\%28197310\%2914\%3A3\%3C693\%3AMWDIUL\%3E2.0.CO\%3B2-7

NOTE: The reference numbering from the original has been maintained in this citation list. 
http://www.jstor.org

\title{
LINKED CITATIONS \\ - Page 4 of 4 -
}

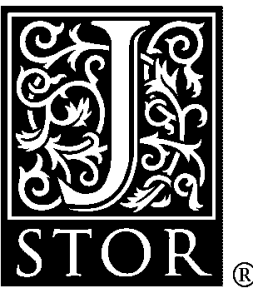

\author{
On Estimation of a Probability Density Function and Mode \\ Emanuel Parzen \\ The Annals of Mathematical Statistics, Vol. 33, No. 3. (Sep., 1962), pp. 1065-1076. \\ Stable URL: \\ http://links.jstor.org/sici?sici=0003-4851\%28196209\%2933\%3A3\%3C1065\%3AOEOAPD\%3E2.0.CO\%3B2-C
}

Post-World War II Immigration to the United States: America's Latest Newcomers David M. Reimers

Annals of the American Academy of Political and Social Science, Vol. 454, America as a Multicultural Society. (Mar., 1981), pp. 1-12.

Stable URL:

http://links.jstor.org/sici?sici=0002-7162\%28198103\%29454\%3C1\%3APWIITT\%3E2.0.CO\%3B2-1

\section{Remarks on Some Nonparametric Estimates of a Density Function}

Murray Rosenblatt

The Annals of Mathematical Statistics, Vol. 27, No. 3. (Sep., 1956), pp. 832-837.

Stable URL:

http://links.jstor.org/sici?sici=0003-4851\%28195609\%2927\%3A3\%3C832\%3AROSNEO\%3E2.0.CO\%3B2-X

Immigrant Earnings, Relative to What? The Importance of Earnings Function Specification and Comparison Points
A. M. Yuengert
Journal of Applied Econometrics, Vol. 9, No. 1. (Jan. - Mar., 1994), pp. 71-90.
Stable URL:
http://links.jstor.org/sici?sici=0883-7252\%28199401\%2F03\%299\%3A1\%3C71\%3AIERTWT\%3E2.0.CO\%3B2-F

NOTE: The reference numbering from the original has been maintained in this citation list. 